\title{
Kırsal Yaşamın Mimari Göstergesi Geleneksel Köy Evlerinin Düzce Örnekleminde Tartışılması
}

\begin{abstract}
Hüseyin BAYRAKTAR ${ }^{1 *}$
Öz

Geleneksel köy evleri uzun yıllar süre gelmiş farklı yapısal tekniklere ve yaşam biçimlerine göre oluşturularak geçmişten günümüze tarihi bilgileri taşırlar. Bu anlamlı ilişkinin kurulmasında yerinde yapılacak incelemeler ve tespitler hem yapısal hem de oluşum süreci hakkında bilgilerin ayrıntılı olarak elde edilmesini sağlamaktadır. Bu çalışmada, Düzce il merkezine bağlı 14 köyde doğal yapı malzemelerinden özellikle ahşap malzemeyi temel alarak yapılan geleneksel köy evlerinin yapısal özellikleri ve oluşum süreçlerinden bahsedilecektir. Araştırma yapılan her bir köyde ilk olarak yapım tarihi en eski evlerin tespiti yapılmıştır. Daha sonra bu evler arasında yerel mimari özelliği ön planda olan birer örnek ev seçilerek yerinde incelenmiştir. Aynı zamanda yapım tekniği ve yapım süreçleri ile ilgili yörede yaşayan halktan yüz yüze görüşme yoluyla tamamlayıcı bilgiler alınmıştır. İncelemelerde unutulmaya yüz tutmuş geleneksel köy evlerinin yapım teknikleri ve oluşum süreçleri hakkında bilgiler karşılaştırmalı olarak tablo üzerinde gösterilmiştir. Tabloda her bir eve ait fotoğraf, plan özellikleri, malzeme, dış ölçüler, yönlendirme gibi bilgiler verilmiştir. Metin içerisinde bazı evlere ait plan detayları ve yapım teknikleri oluşum süreçleri ile birlikte sunulmaktadır.
\end{abstract}

Anahtar Kelimeler: Düzce, Köyler, Geleneksel Köy Evleri, Ahşap Malzeme

\section{Architectural Indicator of Rural Life Discussion of Traditional Village Houses in Duzce Sample}

\begin{abstract}
Traditional village houses have been built according to different structural techniques and lifestyles that have been coming for many years and carry historical information from past to present. On-site examinations and determinations in establishing this meaningful relationship provide detailed information on both structural and formation processes. In this study, the structural features and formation processes of traditional village houses built on natural building materials, especially wooden materials, in 14 villages of Düzce province center will be mentioned. In each of the researched villages, the oldest houses were built. Later, among these houses, a sample house with a local architectural feature was chosen and examined on site. At the same time, supplementary information was obtained from the people living in the region regarding the construction technique and production processes through face-to-face interviews. Information about the construction techniques and formation processes of traditional village houses, which have been forgotten in the examinations, is shown in the table comparatively. In the table, information such as photograph, plan features, material, external dimensions, orientation are given. In the text, plan details and construction techniques of some houses are presented together with the formation processes.
\end{abstract}

Keywords: Düzce, Villages, Traditional Village Houses, Wood Materials

\footnotetext{
${ }^{1}$ Düzce Üniversitesi, Kaynaşlı MYO, Mimarlık ve Şehir Planlama Bölümü, Yapı Ressamlığı Programı

* İlgili yazar/Corresponding author: huseyinbayraktar@duzce.edu.tr 


\section{GíRiş}

Barınma gereksinimi eskiden günümüze süregelen bir zorunluluk olmuştur. Barınma intiyacını zorunlu kılan temel faktörlerin başında ise yağmur, kar gibi tabiat olaylarına karşı korunma gelmektedir (Arslantaş, 2014, s.325). Başlangıçta barınma ihtiyacı tabiat olaylarından korunma amaçlı iken sonraları barınma intiyacı insanlar için bir yere ait olma duygusunu oluşturmuş ve "ev" kavramı ortaya çıkmıştır. Ev bir yuva kavramı ile eşleşerek yaşamın en önemli referans merkezlerinden biri olmuştur (Ersoy, 2003, s.124). İlerleyen dönemlerde ev olgusu yapı tanımı içerisine alınarak farklı yapım süreç ve teknikleri uygulanmış, tarihsel değişimlerle birlikte yapısal gelişmeler göstermiştir. Bunlardan en önemlisi toprak, ahşap ve taşın işlenmesi ile oluşturulan evlerdir. Bu tip evler günümüzde geleneksel mimari özelliğinde yapılmış konutlar olarak adlandırılmaktadır. Geleneksel mimaride evler çevresel faktörler ile uyumlu, doğal görünümlü, yapısı itibariyle farklı değişikliklere uğrayabilen özelliklere sahiptir (Şenoğlu, 2003, s.46). Günümüzde geleneksel mimari özelliklerini kentlerde devam ettiren yapılar çok olmasa da; kırsal bölgelerde varlıklarını sürdürmektedirler.

Yapı tekniğinin gelişimi ve kullanılacak malzemenin uygunluğu yapıyı oluşturan iki önemli etkendir. Geleneksel mimaride yapı tekniği ve malzemenin bölgeye göre geliştiği görülmektedir. Örneğin Batı Anadolu'nun kuzeyinde yerel mimariyi anlatan konut tipi coğrafi özelliklerin yanı sıra iklim, malzemenin bulunabilirliği ve geçmişten gelen yapım geleneğine göre şekillenmiştir (Kocabıçak ve Pilehvarian, 2017, s.398). Türkiye'nin Ege ve Doğu Anadolu Bölgelerinde taş ve kerpiç ağırlıklı malzemeden oluşmuş geleneksel yapılar ağırlıkta iken; Karadeniz Bölgesinde ahşap ağırlıklı malzemeden meydana gelen geleneksel yapılar ağırlıktadır. Mimari gelişmeler sadece yapıda kullanılan malzemeler ile değil iklim özelliklerine göre de değişmektedir. Özellikle sıcak bölgelerde iklime bağlı olarak Doğu ve Güneydoğu Anadolu'da düz damlı mimari ön plana çıkar iken, yağışlı bir iklime sahip Karadeniz Bölgesinde çatılı evler ön plana çıkmaktadır. Sosyo-ekonomik ve kültürel farklıılılar da mimari planların değişiminde önemli birer etken olmuştur. Osmanlı döneminde ortaya çıkan "Hayatlı Ev" olarak adlandırılan konutlar özgün değerini korumaktadır. Kırsal alanlarda merkeze dönük yaşam koşulları çekirdek aile kavramına dönüşerek ev planlarına yansımış ve "Hayatlı Ev" tarım ağırlıklı yerlerde yaşayanlar tarafından kırsal alanlarda gelişen bir konut tasarımı haline gelmiştir (Kuban, 2007, s.471). Hayatı Ev odaların ortak bir alana açılarak büyük ailenin bir arada oturup zaman geçirdiği ve muhtemel işlerin birlikte yapıldığı sofa olarak da adlandırılan bir alandır. Ev içerisinde yeme-içme, sosyal birliktelik, iş paylaşımları gibi hayatın içinden faaliyetlerin sürdürüldüğü sofa (hayat) günümüz modern evlerinde salon olarak adlandırdığımız yerde yapılmaktadır. Bu sosyo-kültürel durum "Hayatlı Ev" kavramını destekleyen her yönüyle geleneksel mimarinin ana teması olmuştur.

Geleneksel evler imece usulü ile birlikte çalışılarak oluşturulmaktadır. Malzeme tedarikinden inşa süreci dahil tüm işler birlikte yapılmaktadır. Bu yüzden geleneksel evler insan el emeği ile oluşturulan özgün eserler olarak ortaya çıkmıştır. Geleneksel evlerin oluşumunda insanların intiyaçları, bölgesel özellikler ve çevre-mekan ilişkisi kurgusu ön plana çıkmaktadır (Burkut, 2014,s.147). Osmanlı mimarisinin okunduğu geleneksel evlerin yapım süreçleri ve plan tipolojileri birbirlerine benzemektedir. Bölgesel faktörlere göre seçilen malzemeler, evden avluya, avludan sokağa kurulan ilişki, planlarda ortak yaşam alanı sofa ya da hayat gibi kurgular evlerin benzer özelliklerde oluşturulduğunu göstermektedir (Dikmen ve Toruk, 2014, s.100; Yasa, 2016, s.47; Bozkurt ve Altınçekiç 2013, s.71). 
Yerel mimariyi gelecek nesillere aktarmak ve bu alanda yapılacak çalışmaları artırmak hem korumada hem de sürdürülebilirlikte önemlidir (Ovalı ve Delibaş, 2016, s.517). Yerel mimariyi korumak ve gelecek nesillere tanıtmak toplumsal bir görevin yanında kültürün kaybolmaması adına bir zorunluluktur. Korumada ve gelecek nesillere yerel mimariyi yani halk mimarisini aktarmanın birinci yolu ise bu alanda yapılacak çalışmalardır (Davulcu, 2009, s.690). Korumada yerinde kullanımının sağlanması evlerin geleceğe aktarılmasında önemli bir adım oluşturacaktır (Yaldız ve Asatekin, 2016, s.163). Kırsal bölgelerde gitgide sayıları azalan geleneksel evlerin gelecekte belki de bir daha görülememe intimali olacak ve bulundukları bölgenin kültürel mirası da kaybolabilecektir (Alkan, 2018, s.120). Koruma geleneği genellikle evin yapımında emek vermiş veya evin içerisinde yaşamını sürdürerek birçok anılar barındıranlar tarafından sürdürülmektedir. Bu kişiler evlerden ayrıldığında ne yazık ki evler ya terk edilmekte ya da yıkılarak yerine beton evler yapılmaktadır.

Geleneksel evlerde özellikle ahşap önemli bir yapısal eleman olarak çokça tercih edilmiştir. Ahşap kolay işlenebilmesi, dayanımı, çevre dostu ve geri dönüşümü ile sürdürülebilir bir malzemedir (Bozkurt, 2011, s.117). Ahşabın kullanışlı ve sağlıklı bir malzeme olması geleneksel evlerde kullanımını artırmıştır. Özellikle evlerin yapısal sistemlerinde; dikmelerde, döşemelerde, çatılarda, kapı ve pencerelerde kullanımının yanında tavanlarda ve evlerin dış cephelerinde süsleme malzemesi olarak kullanılmıştır. Toprak hem örtücü hem de topraktan üretilen kerpiç tuğla gibi yapı malzemeleri ile taşıyıcı özellikte kullanılmıştır. Ahşap çatkılı karkas sistem arasına dolgu olarak topraktan yapılan kerpiç ve yine duvarın örtülmesi için sıva olarak toprak çamur sıva kullanılmıştır. Topraktan yapılan kerpiç tuğlalar ve yine topraktan yapılan çamur sıva içerisinde kil, saman ve su katılarak yapılmaktadır. Sağlıklı bir malzeme haline gelen bu malzeme içerisine herhangi bir zararlı katkı maddesi katılmamaktadır (Özgünler, 2017, s.40). Günümüz yapılarında ahşap ve topraktan üretilen yapı malzemelerinin kullanımları devam etmektedir.

Osmanlı mimarisi/Türk evi modeli çatılı ahşap karkas sistemli, "Hayatı ev" sofa merkezli plan tipinde oluşmuştur (Kuban, 2007, 471). Türk evi, Osmanlı devletinin hakimiyet kurduğu özellikle Rumeli ve Anadolu bölgelerinde yerleşmiş, buralarda gelişim göstermiş ve neredeyse 500 sene buralarda kalmayı başararak kendi meziyetlerine göre ortaya konulan ev tipidir (Eldem, 1954, s.11). Önemli bir birikimin, uğraşın ve kültürün harmanlanması sonucu ortaya çıkmış Türk evi plan tipinde evlerin yapımı uzun yıllar hem kentlerde hem de kırsal da devam etmiştir.

Günümüzde Geleneksel Türk evi örneği hem kırsalda hem de kentlerde azalım göstermektedir. Geleneksel Türk evinin azalmasında; savaşlar, yangınlar gibi olayların yanı sıra Türk evinin değerini anlayanların sayısının yetersizliği, doğal yaşam tarzı olan bahçe ve tabiattan uzaklaşma, Avrupa tarzı kübik ev modeline geçiş Türk evinin git gide azalmasına neden olmuştur (Eldem, 1954, s.12). Günümüzde geleneksel köy evleri, Osmanlı mimarisinin/Türk evinin birer örnekleri olarak varlıklarını zor da olsa ancak bazı kırsal bölgelerde sürdürebilmektedir. Bu evlerin detayları ile birlikte gün yüzüne çıkarılmaları ve yaşatılmaları gerekmektedir.

Geçmişten günümüze ustalık aktarımı ile dış faktörlerin etkilerine karşı geliştirilen teknik ve uygulamalar sayesinde günümüze kadar ulaşmış geleneksel evler modern mimariye örnek olmaya devam etmektedir. Burada önemle üzerinde durulması gereken hususlardan birisi bulunduğu bölgeye kimlik kazandıran geleneksel evlerin özelliklerinin saptanması, yapım süreçlerinin anlaşılması ve bu değerlerin korunmasına önem verilmesidir (Koçan, 2012, s.95). Geleneksel evlerin korunması, yapısal özelliklerin, yapım süreçlerinin kayıt altına alınarak gelecek kuşaklara aktarılması kültürel bir olgu 
olan geleneksel mimarinin yaşatılmasını ve yüzyıllardır süre gelmiş tekniklerin sürdürülebilirliğini sağlamış olacaktır.

\section{ARAŞTIRMA BÖLGESI}

\subsection{Düzce}

Batı Karadeniz Bölgesinde bulunan Düzce ili Neolitik Çağdan (M.Ö 8000-5500) kalma izlerin bulunduğu bir yerleşim yeridir. Yüzölçümü 2492 km² ve 2018 yılı nüfusu 387844 olan Düzce'nin toplam 7 ilçesi (Akçakoca, Cumayeri, Çilimli, Gölyaka, Gümüşova, Kaynaşlı ve Yığılca) bulunmaktadır. Bu ilçelerden Diapolis (Akçakoca) ve Prusias Hypium (Konuralp) antik yerleşimleri Helenistik ve Roma dönemlerine ait arkeolojik kalıntılara sahiptir. Düzce bölgesinde M.Ö. 297'de kurulan Bithynia krallığı M.Ö. 74 yılında Roma İmparatorluğuna devredilmiştir. Osmanlı İmparatorluğunun ikinci padişahı Orhan Gazi tarafından bölgeye gönderilen iki komutandan Akçakoca Bey 1319 yılında Akçakoca (Diapolis)'i, Konuralp Bey ise 1323 yılında Konuralp (Prusias ad Hypium)'si feth ederek bölgede hakimiyet Osmanlı İmparatorluğuna geçmiştir. Osmanlı İmparatorluğundan sonra bölge 1923 yılında kurulan Cumhuriyet dönemi devrine girmiştir (Düzce Taşınmaz Kültür Varlıkları Envanteri, 2014). 17 Ağustos 1999 Marmara ve 12 Kasım 1999 Düzce Depremlerini yaşayan ve ağır hasarlar alan Düzce 09 Aralık 1999 tarih ve 23091 Sayılı Bakanlar Kurulu kararıyla ilçe statüsünden çıkarılarak Türkiye'nin İl statüsündeki 81. ili olmuştur. Şekil 1'de Arcgis yazılım programında düzenlenen Düzce İlinin yer bulduru haritası verilmektedir.

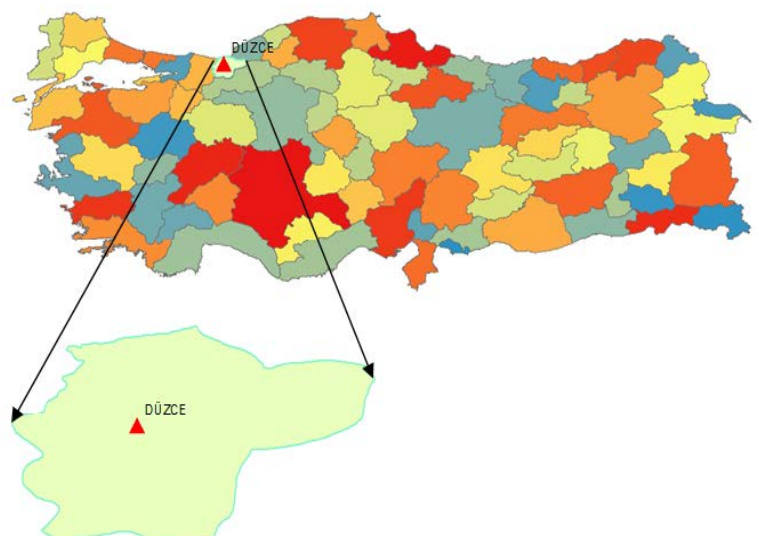

Şekil 1. Düzce ilinin Türkiye haritasındaki yeri (Arcgis Yazılım Programı)

Batı Karadeniz Bölgesinde yer alan Düzce ili geniş ormanlık alanlara sahiptir. Bölgede orman alanların yoğun olması ahşap malzemenin kolay bulunmasını ve ahşap işçiliğinin gelişmesini sağlamıştır. Bundan dolayı Düzce ilinde var olan geleneksel evler ağılıklı olarak ahşap iskeletli yapım sisteminde yapılmıştır. Aynı zamanda iklimsel olarak yağışların bol yaşandığı Karadeniz iklimine yakın olduğundan yağmur sularını kolay uzaklaştırmak amacıyla evlerin çatıları kırma çatı şeklinde yapılmıştır. Geleneksel evler, temelinde taş bloklar üzerine ahşap hatıllar, dikmeler ile çaprazlamalar, duvarları ise taş, tuğla, kerpiç ya da çiteme (dal örgü) dolgulu, çatılı mimari örneğinde üretilmiştir. Bu tür yapım tekniğine hımış denmektedir. Yakın bölgelerde de benzer yapı sisteminde üretilmiş geleneksel evler bulunmaktadır. Örneğin Osmanlı'dan kalma sivil mimari örneklerinin çokça bulunduğu Sakarya iline bağlı Taraklı ilçesinde çatılı mimari, genelde karkas sistemi ahşap çatkılı, duvarları kerpiç dolgulu ve yer aldığı coğrafyanın malzemesine, iklim özelliğine göre şekillenmiş yapı tipolojisi bulunmaktadır (Apay, Önür ve Bideci, 2019, s.162). Bölgenin sahip olduğu coğrafi özellikler geleneksel evlerin oluşumuna yön veren önemli bir göstergedir. 


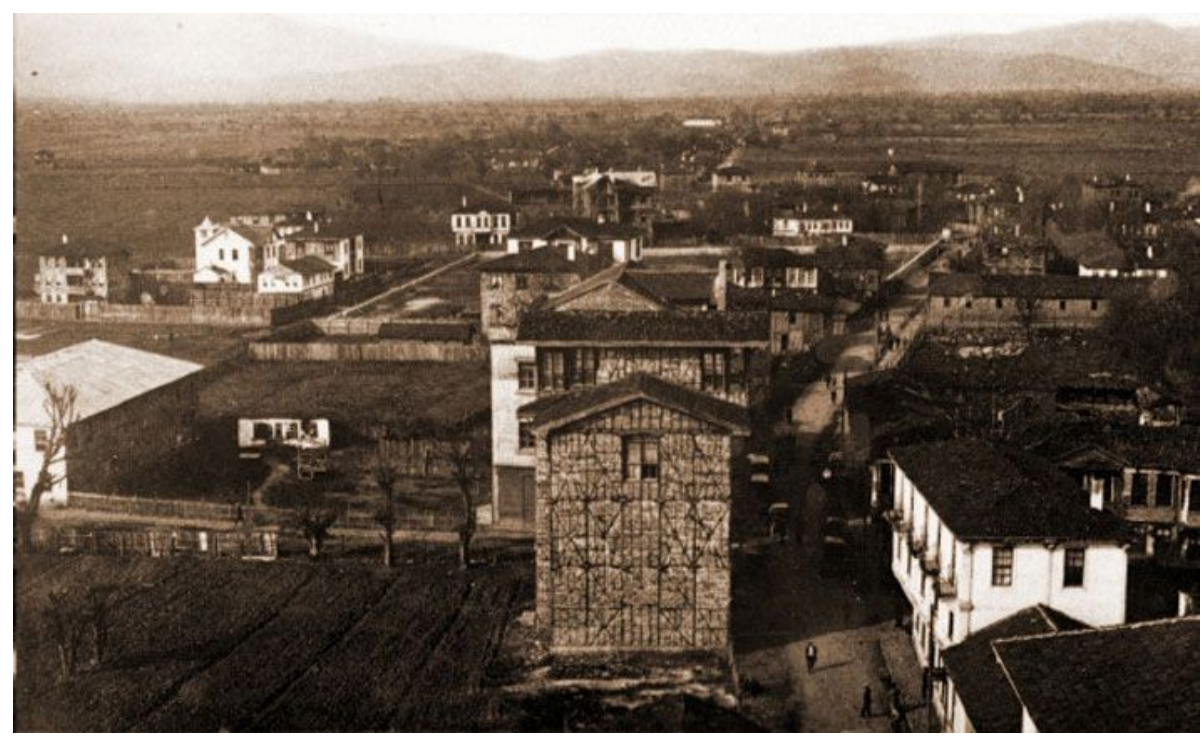

Şekil 2. Düzce'nin merkezinden bir bölge, 1929 yılında çekilen eski Akçakoca caddesi (URL 1)

Şekil 2'de Düzce'nin 1929 yılına ait fotoğrafında evlerin geleneksel yöntemlerle yapıldığı, genellikle 2-3 katlı hımış ya da yığma yapılardan oluşan ayrık nizamda yapılmış kent merkezinden görünümü yer almaktadır. Hımış tipi yapılar ahşap çerçeveli duvarlar arasında kerpiç, tuğla, taş malzemelerle doldurulmasıyla oluşturulan yapılardır (Bayraktar, N. T. ve Kishalı, E. 2013, s.12). Düzce'nin düz bir ova üzerinde kurulu olması ve verimli arazilere sahip olması tarımsal faaliyetleri artırmıştır. Geniş tarım arazilerinin yanında geleneksel evlerin bahçeleri de geniş bırakılarak bahçeler tarıma elverişli hale getirilmiştir.

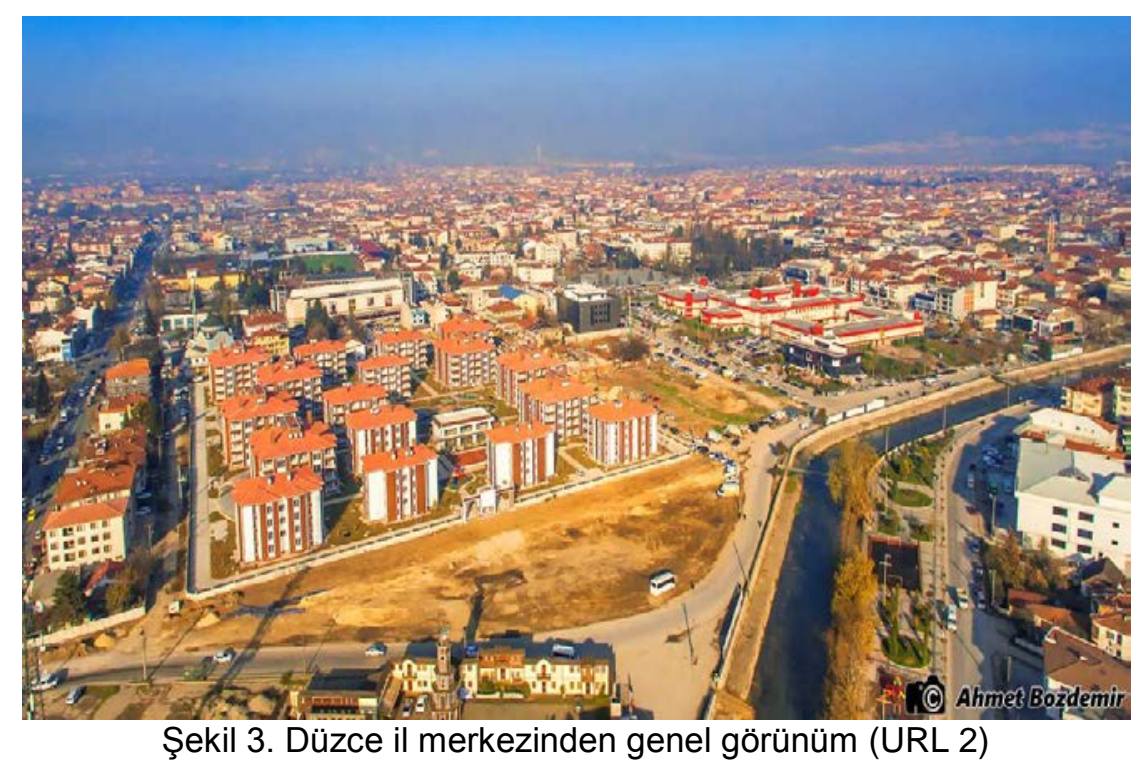

Şekil 3'de ise Düzce il merkezinin günümüzden bir görünümü yer almaktadır. İl merkezi genelde 4-5 katlı betonarme yapılardan oluşmuş, bitişik yapı nizamın yoğunlukta olduğu bir yer haline gelmiştir. Kent merkezinde inşa edilen toplu konutlar, siteler ve alışveriş merkezleri ile daha çok ticari bir şehir yaşamına dönüşmüştür. Fakat Düzce'nin köylerinde, kırsal bölgelerinde hala hayvancılık, tarımsal faaliyetler ve geleneksel tip evlerin varlığı sürmektedir. 


\subsection{Köyler}

Araştırma bölgesi olan Düzce il merkezine bağlı 14 köyde geleneksel köy evleri ile ilgili incelemeler yapılmıştır. Bu köyler; doğudan batıya Asar, Esençam, Gürcüçiftliği, Ozanlar, Yeni Taşköprü, Bahçeköy, Paşakonağı, Karadere Hasanağa, Köprübaşı Ömer Efendi, Selamlar, güneyden kuzeye Derdin, Fındıklı Aksu, Kaledibi ve Düverdüzü köyleridir. Şekil 4'de köylerin Düzce merkeze göre konumlarını gösteren uydu görüntüsü verilmiştir. Genel bir değerlendirmenin yapılabilmesi için köylerin seçiminde sadece bir bölgede olanlar değil Düzce merkez çevresinde yer alan farklı bölgelerden yararlanılmıştır.

\subsubsection{Köylerin nüfus, uzaklık ve rakım bilgileri}

Köylerin nüfus dağılımları değişkenlik göstermektedir. En az nüfusa sahip köy 110 kişi ile Kaledibi iken, en fazla nüfusa sahip köy ise 2049 kişi ile Yeni Taşköprü köyüdür. Kaledibi köyünün rakımının fazla olması ve mesafe olarak da Düzce merkeze uzak kalması nüfusu olumsuz yönde etkilemiş olabilir. Yeni Taşköprü köyü ise rakım olarak düşük, Düzce merkeze mesafe olarak yakın olması, aynı zamanda Düzce'nin batıya doğru gelişim aksı üzerinde bir bölgede yer alması nüfusu olumlu yönde etkilemiş olabilir. Şekil 4'de Google Earth Pro programı kullanılarak araştırma yapılan köylerin merkeze göre konumları gösterilmiştir.

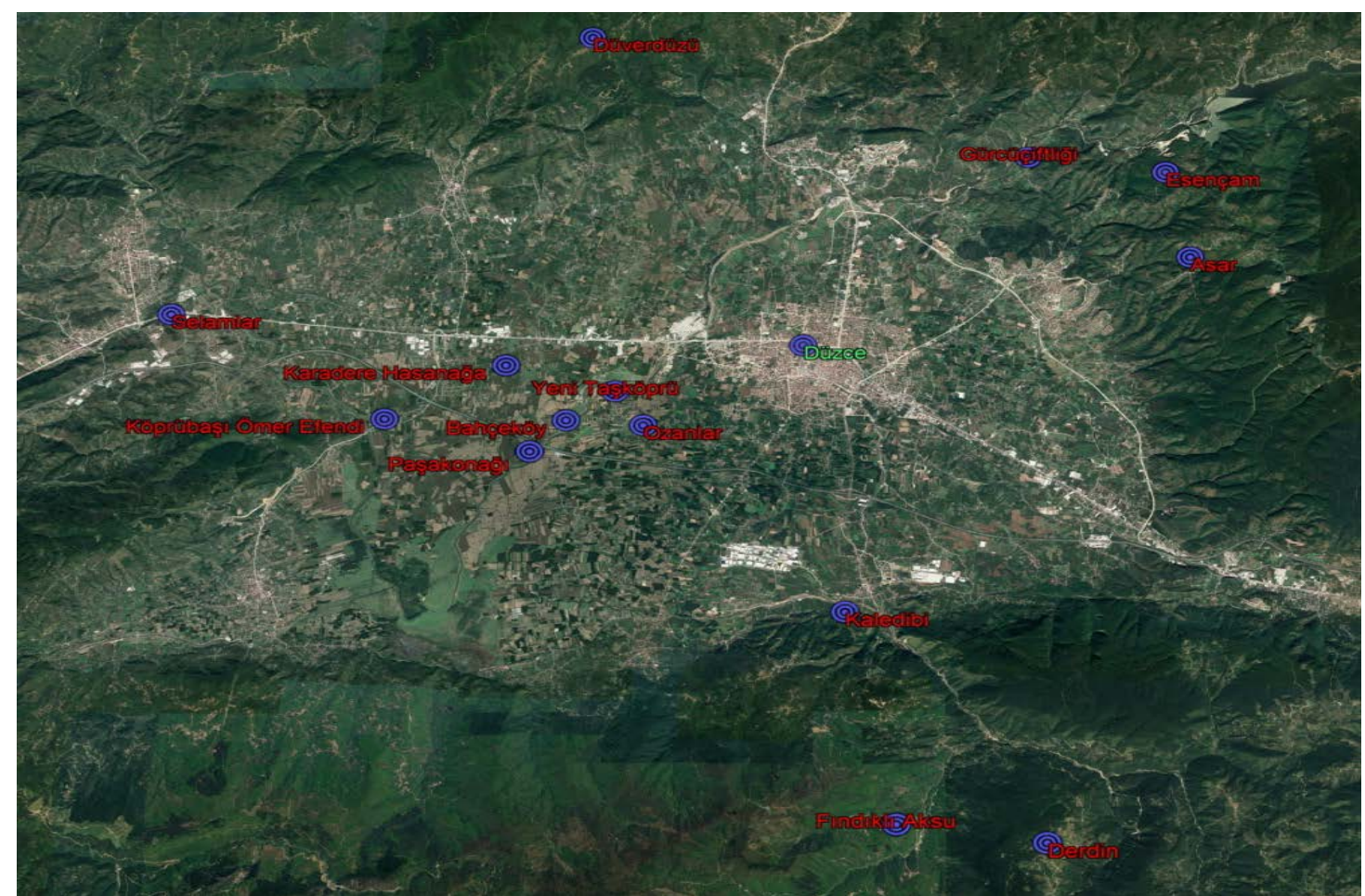

Şekil 4. Düzce merkez ve çevresinde araştırma yapılan köyler ve konumları (Google Earth Pro)

Araştırma yapılan Düzce merkeze bağlı farklı bölgelerde yer alan 14 köyün nüfus, uzaklık ve rakım değerleri Tablo 1'de toplu olarak gösterilmiştir. Rakım ve uzaklık faktörüne göre köylerde nüfus oranları değişebilmektedir. Nüfusun daha yoğun olduğu köylerde geleneksel tipte evlerin oranı da fazladır. Nüfusu azalan köylerde ise terk edilmiş geleneksel köy evleri ya da yeni yapılmış modern evler daha çok göze çarpmaktadır. Düzce merkeze uzaklık ve rakım faktörleri nüfusu dolayısıyla geleneksel köy evleri oranlarının değişkenliğine neden olabilmektedir. 
Tablo 1. Köylere göre nüfus, uzaklık ve rakım bilgileri

\begin{tabular}{|c|c|c|c|c|c|}
\hline OBJECTID * & SHAPE * & Koy adi * & koyler.Nüfus 2017 & Merkezden Uzaklık km & Rakım m \\
\hline 1 & Point & Selamlar & 449 & 16 & 130 \\
\hline 2 & Point & Kaledibi & 110 & 8.72 & 225 \\
\hline 3 & Point & Findiklıaksu & 121 & 15.3 & 654 \\
\hline 4 & Point & Derdin & 328 & 17 & 909 \\
\hline 5 & Point & Asar & 457 & 10.2 & 457 \\
\hline 6 & Point & Esençam & 476 & 10.8 & 479 \\
\hline 7 & Point & Gürcüçiftliği & 807 & 8.43 & 185 \\
\hline 8 & Point & Düverdüzü & 361 & 11.6 & 522 \\
\hline 9 & Point & Ozanlar & 582 & 4.78 & 130 \\
\hline 10 & Point & Yeni Taşköprü & 2049 & 4.95 & 133 \\
\hline 11 & Point & Bahçeköy & 816 & 6.4 & 128 \\
\hline 12 & Point & Paşakonağı & 180 & 7.62 & 126 \\
\hline 13 & Point & Köprübaşı Ömer Ef & 454 & 10.8 & 126 \\
\hline 14 & Point & Karadere Hasanağ & 577 & 7.48 & 128 \\
\hline
\end{tabular}

\section{ARAŞTIRMA YÖNTEMI}

Çalışmada sunulan bilgiler BAP projesi kapsamında elde edilen verilerden uyarlanmıştır. Araştırma öncesinde Düzce İI Kültür ve Turizm Müdürlügü’ne gidilerek Düzce'de geleneksel mimari örneğinde evlerin yer aldığı köylerin isimleri liste halinde alınmıştır. Proje kapsamında yaklaşık 30 köye gidilerek geleneksel mimariye ait veriler toplanmıştır. Bu çalışmada ise sadece 14 köye ait evlerin bilgilerinin verilmesinin sebebi diğer köylere göre bu 14 köydeki evler hakkında daha detaylı bilgilerin edinilmiş olmasıdır. Gidilen 14 köyden her birinde yapım tarihi ve özelliği ile ön plana çıkan her köyden bir ev örneklem olarak seçilmiştir. Araştırmada günümüze kadar ulaşabilmiş geleneksel halk mimarisini, Osmanlı mimarisi/Türk evi konut tipini yansıtan geleneksel köy evleri incelenmiştir. Şekil 5'de araştırma esnasında 2012 yılında fottoğrafları çekilen her bir köye ait geleneksel köy evleri örnekleri verilmiştir.

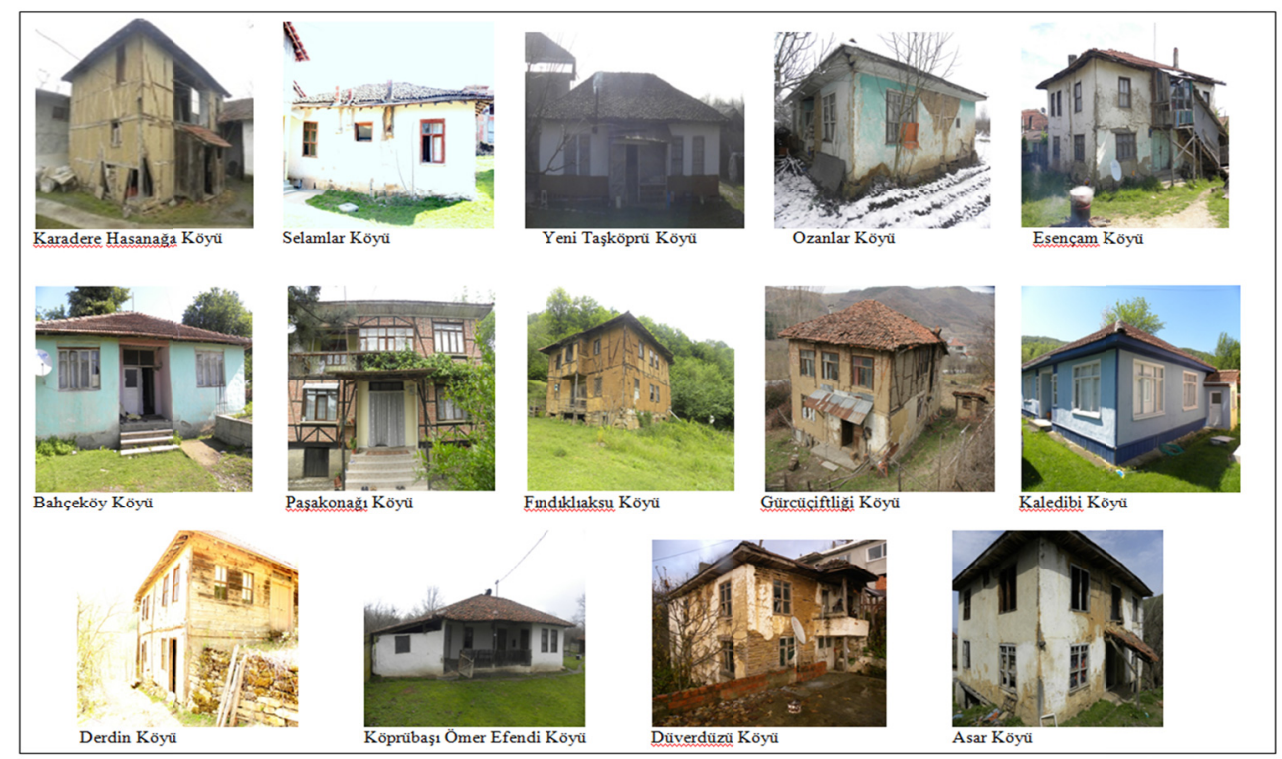

Şekil 5. Çalışmada incelenen geleneksel köy evleri (Fot:Hüseyin Bayraktar)

Geleneksel köy evlerinin yapım tarihi, temel sistemi, yapısal sistem, kullanılan malzemeler, yönlendirmeler, plan tipi ve detaylar gibi teknik bilgiler hakkında incelemelerde bulunulmuştur. Daha sonra evlerin oluşum süreçleri, yaşam biçimleri gibi tanımsal bilgiler elde edilmiştir. Tablo 2'de geleneksel köy evlerine ait teknik bilgilere dayalı detaylar karşılaştırmalı şekilde verilmiştir. Bu sayede araştırma bölgesinde her bir köye ait incelenen evler alt alta verilerek benzerlikler ve farklılıklar karşılaştırmalı olarak analiz edilmiştir. 
Tablo 2. Araştırma bölgesi köylerde incelenen evlerin teknik bilgilerinin karşılaştırılması

\begin{tabular}{|c|c|c|c|}
\hline 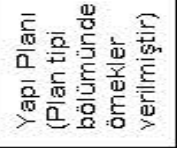 & 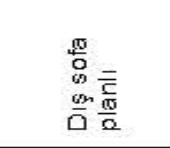 & 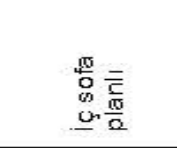 & 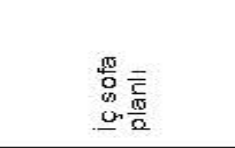 \\
\hline 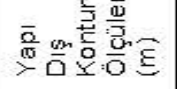 & $\begin{array}{l}\text { 希吉 } \\
\text { vid }\end{array}$ & 希品 & 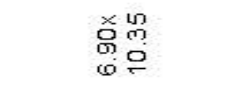 \\
\hline 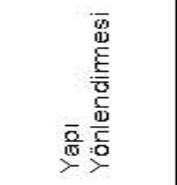 & 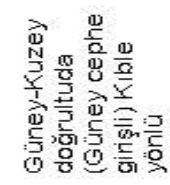 & 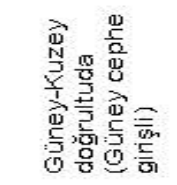 & 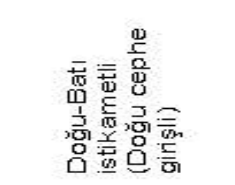 \\
\hline IsIRES epo & מ & 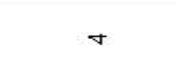 & $\checkmark$ \\
\hline 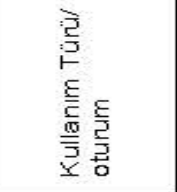 & 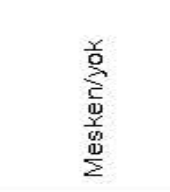 & 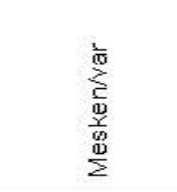 & 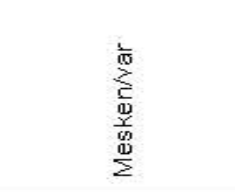 \\
\hline 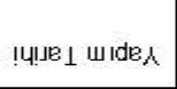 & $\stackrel{\text { Nै }}{\text { के }}$ & 品 & 疍 \\
\hline 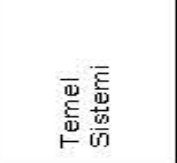 & 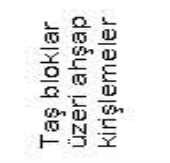 & 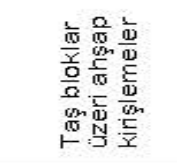 & 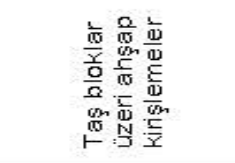 \\
\hline 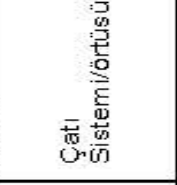 & 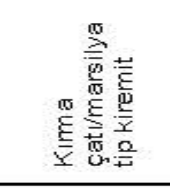 & 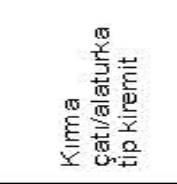 & 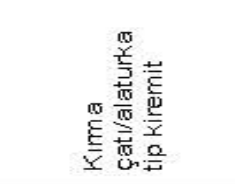 \\
\hline 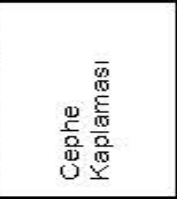 & 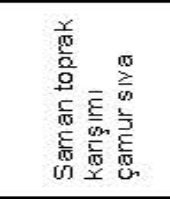 & 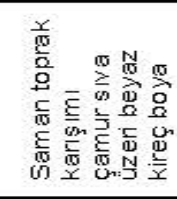 & 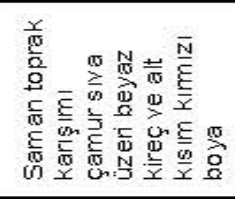 \\
\hline$\sum_{\overline{0}}^{\frac{1}{3}}$ & 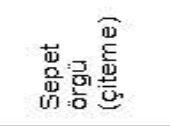 & 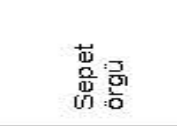 & 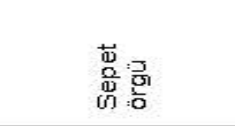 \\
\hline Isikes jey & N & - & - \\
\hline 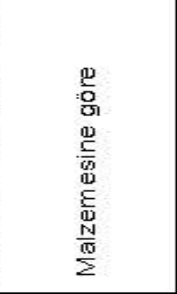 & & 믈 & $\frac{7}{4}+\frac{1}{x}$ \\
\hline 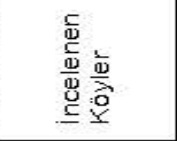 & 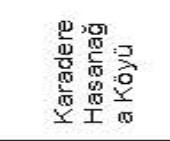 & 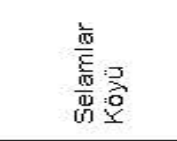 & 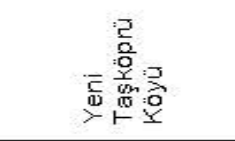 \\
\hline ONEIS & - & $N$ & $m$ \\
\hline
\end{tabular}




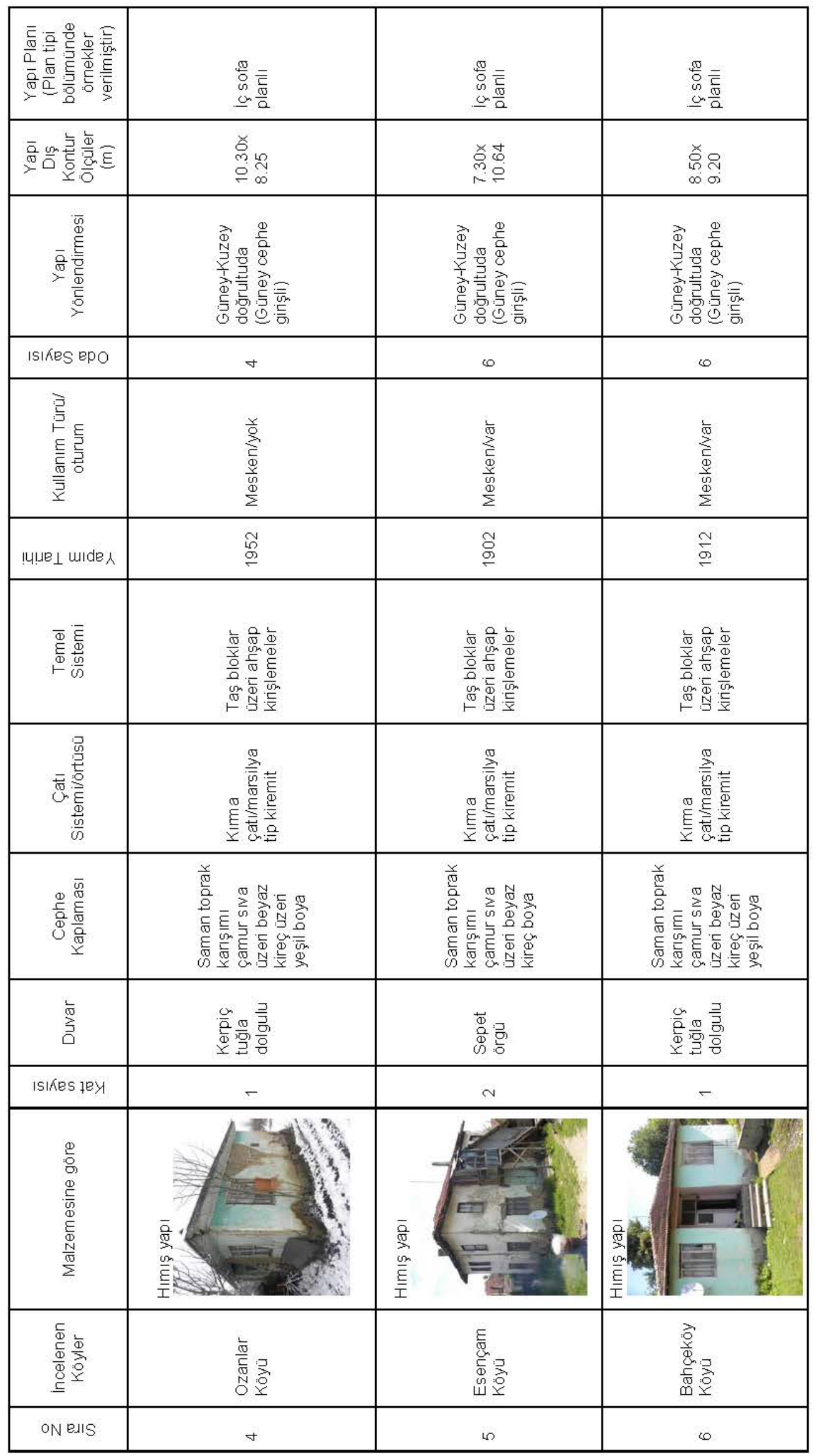




\begin{tabular}{|c|c|c|c|}
\hline 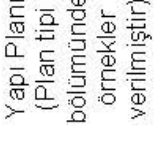 & 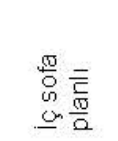 & 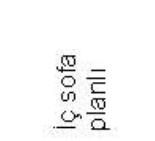 & 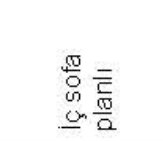 \\
\hline 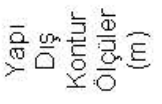 & $\begin{array}{l}\text { 庤导 } \\
\text { 心 }\end{array}$ & 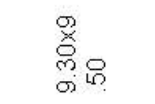 & 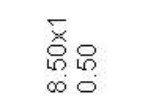 \\
\hline 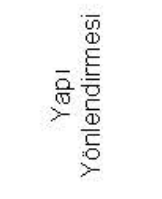 & 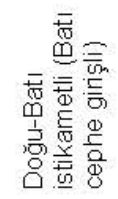 & 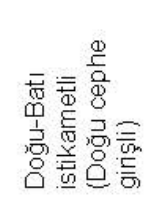 & 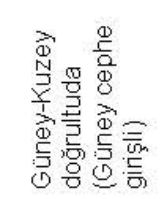 \\
\hline ISIRES ERO & $\infty$ & in & 10 \\
\hline 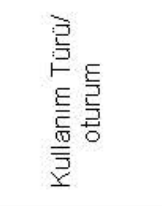 & 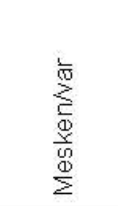 & 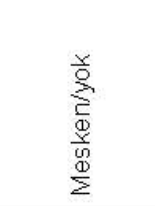 & 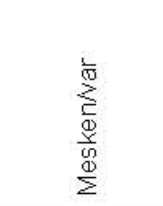 \\
\hline 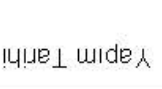 & $\stackrel{\circ}{\circ}$ & 范 & 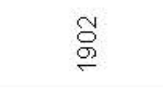 \\
\hline 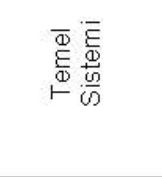 & 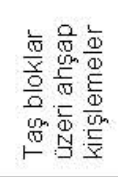 & 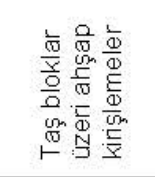 & 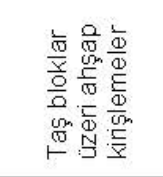 \\
\hline 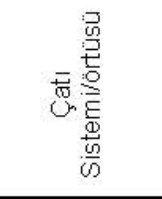 & 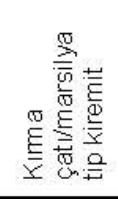 & 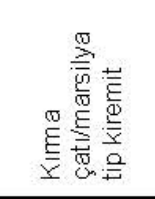 & 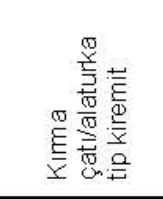 \\
\hline 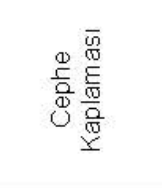 & 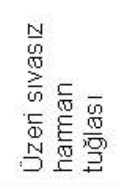 & 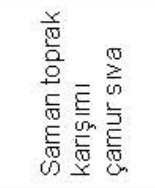 & 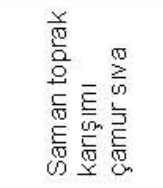 \\
\hline $\begin{array}{l}\text { 产 } \\
\stackrel{3}{\Delta}\end{array}$ & 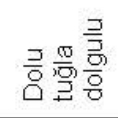 & 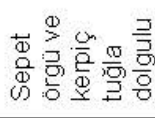 & 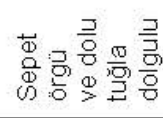 \\
\hline IsIKes jey & n & $\sim$ & $v$ \\
\hline 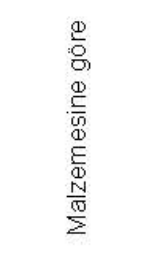 & 8 & Fe? & E \\
\hline 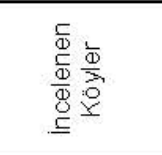 & 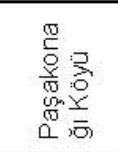 & 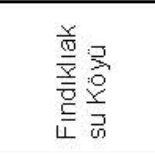 & 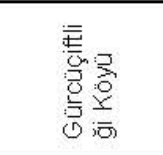 \\
\hline ON EAIS & R & $\infty$ & \\
\hline
\end{tabular}




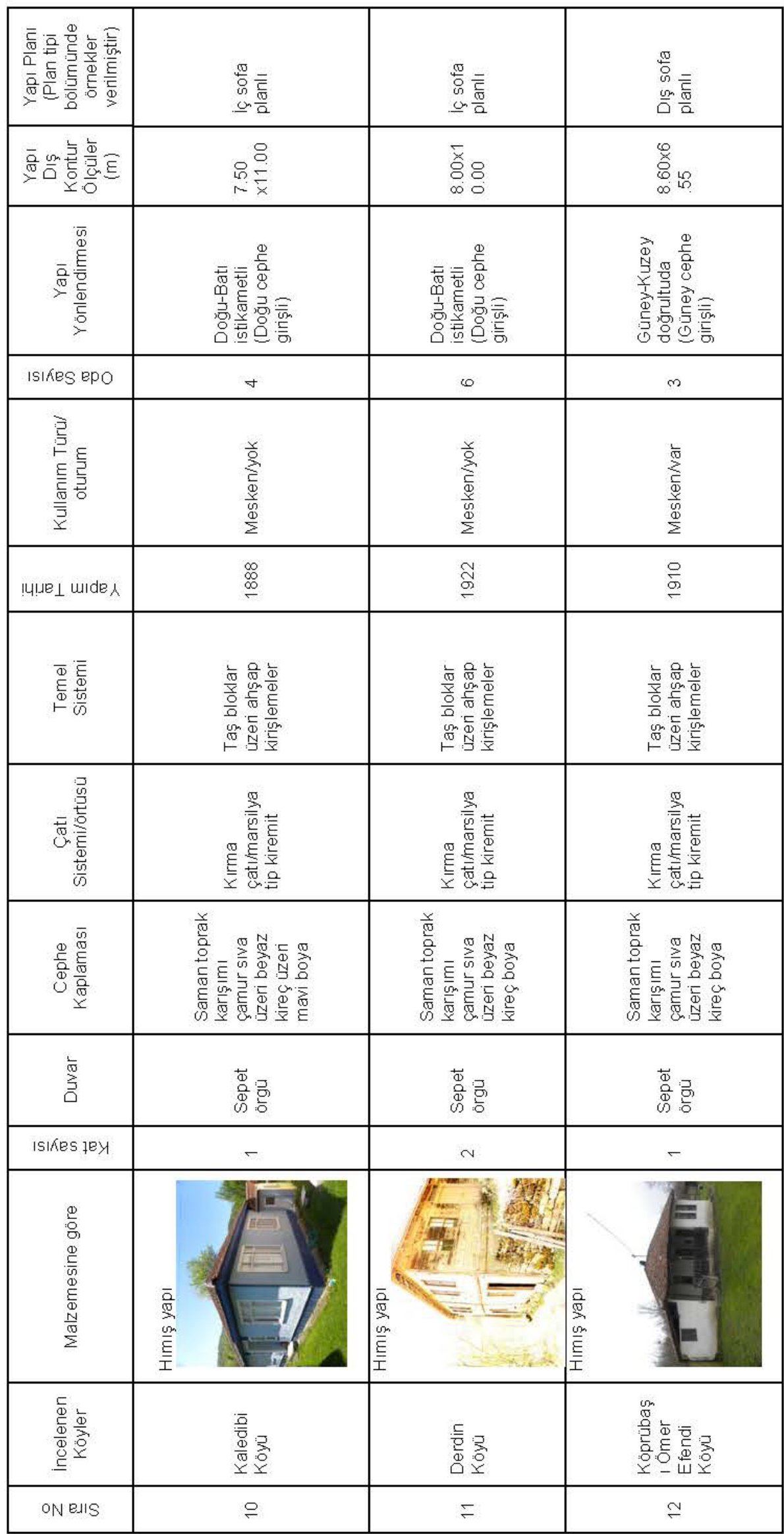




\begin{tabular}{|c|c|c|}
\hline 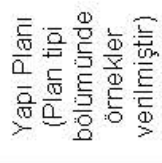 & 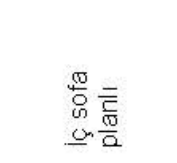 & 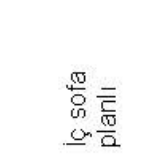 \\
\hline 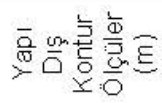 & 兽 & $\begin{array}{l}\text { Oू. } \\
\text { ồ } \\
\infty\end{array}$ \\
\hline 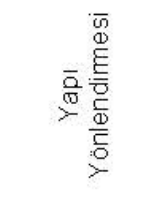 & 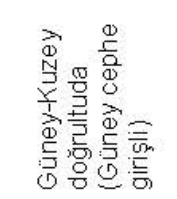 & 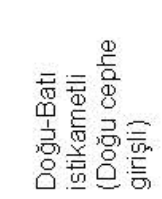 \\
\hline ISIKES epo & $n$ & $\omega$ \\
\hline 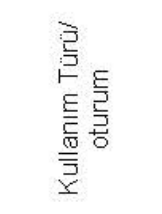 & 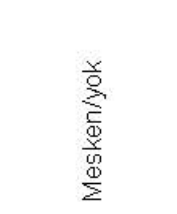 & 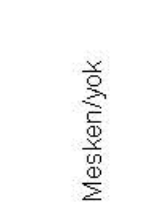 \\
\hline lyue $\perp$ uıde & 宇 & $\stackrel{\leftrightarrow}{\stackrel{\leftrightarrow}{\circ}}$ \\
\hline 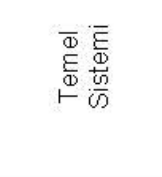 & 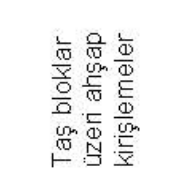 & 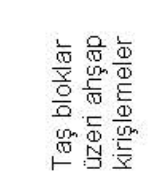 \\
\hline 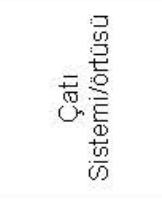 & 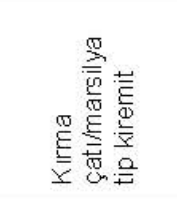 & 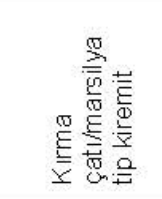 \\
\hline 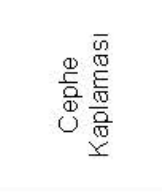 & 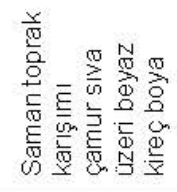 & 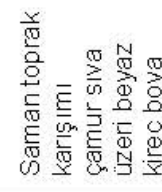 \\
\hline 产 & 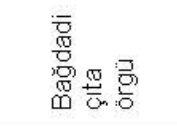 & 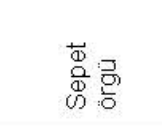 \\
\hline IsIfRes jey & $\sim$ & v \\
\hline 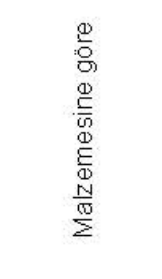 & & \\
\hline 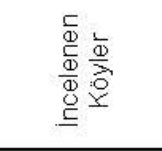 & 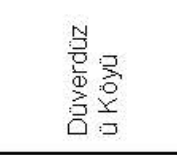 & 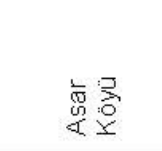 \\
\hline ONEASS & $\stackrel{m}{=}$ & 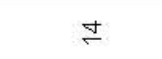 \\
\hline
\end{tabular}


Evler hakkında bilgiler mülakat, ölçü alımı ve fotografik belgeleme yöntemiyle sağlanmıştır. Evlerin yapım süreçleri ve kullanılan malzemeler ile ilgili bilgiler ev sahipleri ya da evin yapılışını bilenler ile mülakat yoluyla daha önce hazırlanmış veri föylerine aktarılmıştır. Ev hakkında mülakat yoluyla alınan bilgiler sonrasında evin dış ve iç ölçüleri alımında uzunluk ölçümünde kullanılan 5 metrelik, 20 metrelik şerit metreler ve yükseklik ölçümü için 5 metre boyunda mira kullanılmıştır. Son olarak evin dışarından ve içeriden fotoğrafları yüksek çözünürlüklü bir fotoğraf makinesi kullanılarak çekilmiştir. Her bir eve ait yapım tarihi, kullanılan malzeme, yapım tekniği, yönlendirme gibi veriler fotoğraflarla birlikte incelenen evin dosyasına işlenmiştir. Daha sonra 14 köyde yapılan çalışma sonuçları bir tablo üzerinde gösterilerek evler arasındaki özellikler toplu olarak gösterilmiştir.

\section{TARTIŞMA VE BULGULAR}

\subsection{Düzce kırsalında evlerin oluşum süreci ve karakteristik özellikleri}

Köylerin yerleşim olarak konumları düzlük araziler ya da eğimli arazilerdir. Düzlük ya da eğimli arazilere yerleşim kararında yöre halkının daha önceki deneyimleri, yaşam biçimleri belirleyici olmaktadır. Araştırma bölgesi Düzce ili ağırlıklı olarak dışarıdan göç alan bir yerleşimdir. Bundan dolayı Düzce'ye göç edenler daha önce sulak düz arazilerde yaşamışlar ise yine göç edilen yerde alıştıkları aynı arazi şartlarına sahip arazileri seçmektedirler. Eğimli arazilere sahip ise göç ettikleri yerde yine eğimli araziler tercih edilmektedir. Çünkü topoğrafik yapı insanların yaşamsal faaliyetlerini sürdürmede önemli bir etken olabilmektedir. Köylerde düz arazilere sahip aileler tarımsal faaliyetlerde daha deneyimli iken eğimli arazilere sahip aileler ise hayvancılık, ormancılık gibi işlerde deneyim sahibidirler. İncelenen köylerde mülakatlarda arazi tecrübesine göre köy yerinin belirlendiği anlaşılmıştır. Evlerin oluşumu önceki deneyimlerden yola çıkılarak ve coğrafi özelliklerin gerektirdiği şartlara göre biçimlendirilmektedir. Evlerin yapıldığı yerler genellikle dere kenarlarına yakın bölgelerdir. Suyun bulunduğu yerlerde yaşam her yönüyle daha rahat sürdürülebilmektedir. Su ve toprak köy yerlerinin seçiminde önemli bir yer tutmaktadır. Geleneksel köy evlerinde kullanılan tüm malzemeler çevreden elde edilen doğal malzemelerdir. Köylerin Batı Karadeniz Bölgesinde yer alması ahşaba ulaşımı kolaylaştırmıştır. Bu durum evlerin ve müştemilatların yapımında ahşabın ağırlığını fazlasıyla hissettirmektedir. Killi toprağın da bölgede yoğun olarak bulunması kerpiç, çamur sıva gibi malzemelerin elde edilmesini kolaylaştırmıştır. Taş, ahşap ve toprak gibi malzemeler geleneksel köy evlerinin oluşumunda büyük tol oynamışlardır.

Köy yerinde yapılan işlerin çoğunda imece usulü birlikte yardımlaşma vardır. Bu durum tarım işlerinde ve hayvancılıkta aynı şekildedir. İmece usulü aynı şekilde evlerin oluşumunda da kendini göstermiştir. Kimin evi yapılacaksa çevreden evde kullanılacak taş, ahşap ve toprak bulunup erkekler tarafından getirilmektedir. Daha sonra çeşitli kesici aletler ile getirilen malzemeler ev yapımında kullanılacak forma getirilmektedir.

İncelenen geleneksel köy evlerinin tamamı kırma çatı sisteminde ve malzemesine göre hımış yapılardır. Hımış yapıda ahşap dikme ve çaprazlar taşıyıcı olarak kullanılırken taş, tuğla, kerpiç gibi malzemelerde dolgu malzemesi olarak kullanılmaktadır. Köylerde incelenen evlerin taşıyıcı sistemi aynı iken dolgu malzemesi değişkenlik göstermektedir. Şekil 6'da malzemesine göre evlerin oransal olarak grafiği verilmiştir.

Evlerin yapımında da malzemelerin tedarik edilmesinden bir araya getirilmesine kadar birlikte bir çalışma ve yardımlaşma örneği süre gelmiştir. Bu bağ sosyal birlikteliği sağlamaktadır. Geleneksel köy evlerinin yapımında doğal malzemelerin tercih edilmesi bu evlerde büyüyenlerin sağlıklı ve rahat bir ortamda yaşam sürmelerini sağlamıştır. 
Ahşap, toprak gibi sıcak ve nefes alan malzemeler iç konforun artmasını sağlayan malzemelerin başında gelmiştir. Bu tip geleneksel evlerde uzun yıllar yaşayanlar ortamın rahatlıklarından bahsetmektedirler. Incelenen evlerin birinde uzun yıllar yaşamış bir Kaynak Kişi KK2, daha sonra yeni sistemde yapılmış beton bir eve çıkınca sağlık bakımından rahatsız olduğundan bahsetmektedir. Daha önce yaşadıkları geleneksel köy evinde herhangi bir hastalık yaşamamışken yeni beton malzemeden yapılmış evde yaşamaya başladığından beri romatizma başta olmak üzere çeşitli hastalıkların baş gösterdiğinden söz etmiştir.

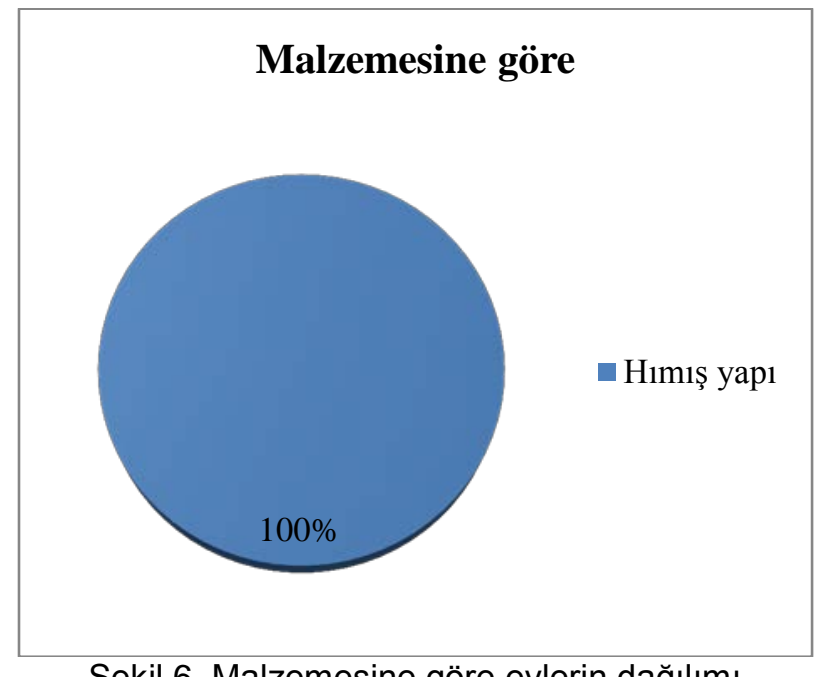

Şekil 6. Malzemesine göre evlerin dağılımı

Geleneksel tip evlerin temelinde dağlardan getirilen sert kaya parçaları (taş bloklar) kullanılmaktadır. Bu kayalar evin dört köşesine veya 6 köşe ve ortalara konulmakta, arazi kotuna göre üstleri düz olacak şekilde yerleştirilmektedir. Genelde taş blokların boyutları ortalama $60 \times 50 \times 50 \mathrm{~cm}$ veya $50 \times 50 \times 50 \mathrm{~cm}$ olmaktadır. Taş bloklar toprağa yerleştirilirken taşın yarısı bazen biraz fazlası toprağa gömülü iken diğer yarısı toprak üzerinde kalacak şekilde konulmaktadır. Taş bloklar üzerine ahşap kirişler ve kirişler üzerine dikmeler oturtulmaktadır. Ahşap karkas sistem genellikle köknar, kestane, meşe ya da kayın ağacından hızarlarla bir iskele üzerinde kesildikten sonra yerine uygulanmaktadır. Evin temelinde kayanın yarısı dışarıda bırakılarak evin doğal havalandırması sağlanmaktadır. Bu sayede ev temelden hava sirkülasyonu yapmakta ve ahşabın nemden etkilenmesi önlenerek kullanım ömrü uzatılabilmektedir. Şekil 7'de geleneksel köy evinin temelinde kullanılan temel taşı ve bırakılan doğal hava boşluğu görülmektedir.

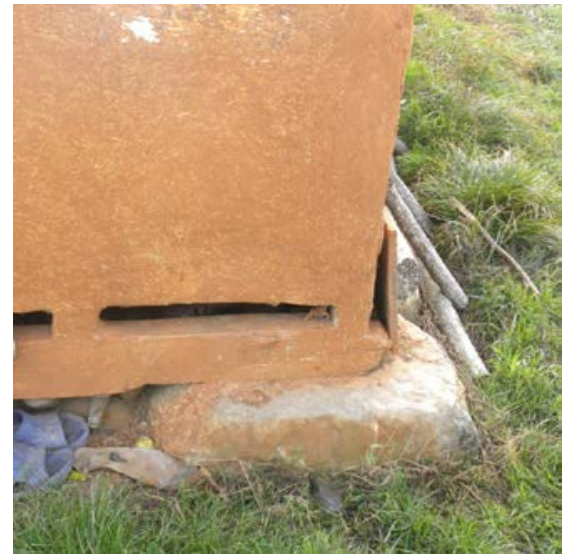

Şekil 7. Temelde tekil temel sisteminde kullanılan taş blok malzeme (Fot.:Hüseyin Bayraktar) 
İncelenen geleneksel köy evleri en fazla iki katlı olarak inşa edilmiştir. Ahşap sistemde yapılan geleneksel köy evlerinin taşıyıcılık özellikleri yapıldığı zamandaki teknik imkanların kısıtlı olmasından ötürü 2 kattan daha fazla katlı evlerin yapımına imkan vermemiştir. İncelenen 14 evden 6'sı 1 katlı iken 8'i 2 katlı olarak inşa edilmiştir. Şekil 8'de evlerin kat sayısına göre dağılımları verilmiştir.

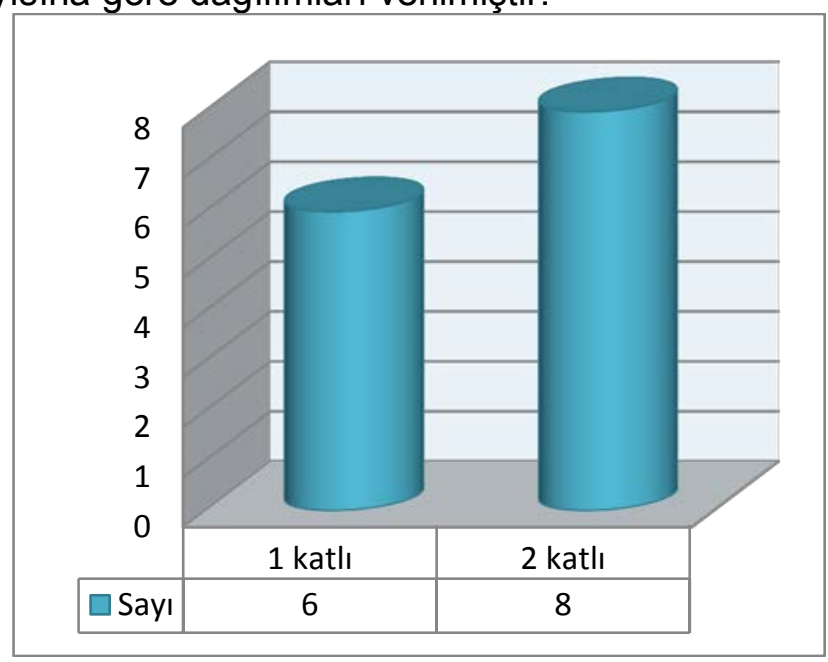

Şekil 8. Evlerin kat sayılarına göre dağılımları

İncelenen evlerde taşıyıcı karkas sistem ahşap dikme ve çaprazlamalar ile yapıldıktan sonra sıra ahşap çatkının aralarının doldurulmasına gelmektedir. Dolgu malzemesi olarak duvarlarda tamamen doğal malzemeler kullanılmıştır. Bunlar; ağaç dalı, kerpiç, tuğla, çıta gibi doğal malzemelerdir. İncelenen evlerde duvarda dolgu malzemesi olarak en çok "çiteme" tekniği denen ağaç dallarından (fındık ya da armut ağacı) yapılan sepet örgü kullanılmıştır. Halk arasında ağaç dallarıyla yapılan örgü şekline "çiteme" denmektedir. Sepet örgü, genelde kış aylarında kesilen armut, fındık veya söğüt ağacı dallarının (2-3cm çapında) ikiye bölündükten sonra orta dikme dalın (ikiye bölünmemiş) etrafında örülmesiyle oluşturulmaktadır. Sepet örgünün tercih edilmesinin başlıca nedenleri arasında malzemesinin kolay bulunabilmesi, taşınabilmesi ve uygulama tekniğinin yaygın olması gelmektedir. Dal/sepet örgüler duvarlarda dolgu malzemesi olarak kullanılmaktadır. Daha sonra içerden ve dışarıdan çamur sıva ile sıvanmaktadır. Sepet örgü üzerinde girinti ve çıkıntılı bir yapı oluştuğundan sıva yüzeye daha iyi tutunmaktadır. Şekil 9'da geleneksel köy evinin duvarında kullanılan sepet örgü (çiteme) örneği verilmiştir.

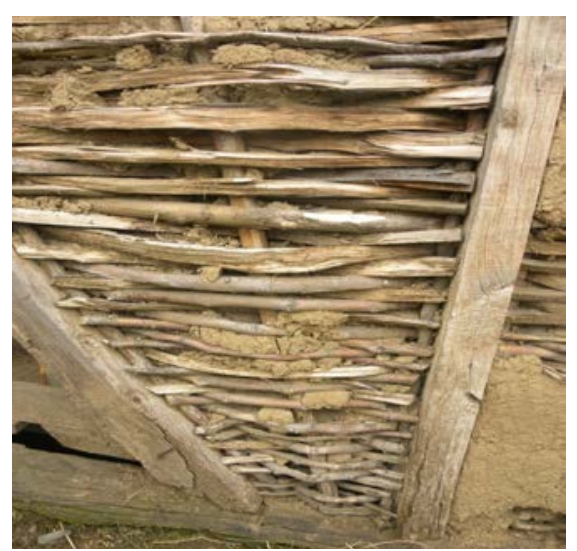

Şekil 9. Halk arasında anılan "çiteme" tekniği ile oluşturulmuş duvar dolgu örneği (Fot.:Hüseyin Bayraktar) 
Duvarlarda kullanılan bir diğer dolgu malzemesi ise kerpiç tuğlalardır. Kerpiç tuğlalar genelde evlerin köşe duvarlarında, baca duvarlarında ve barınak duvarlarında sıkça kullanılmaktadır. Bu sayede evin köşeleri daha sağlam kalmaktadır. Bacalarda kerpiç tuğla tercih edilmesi ile de yangın tehlikesine karşı önlem alınmaktadır. Şekil 10'da geleneksel köy evinin duvarlarında dolgu malzemesi olarak kullanılan kerpiç tuğlalar gösterilmiştir.

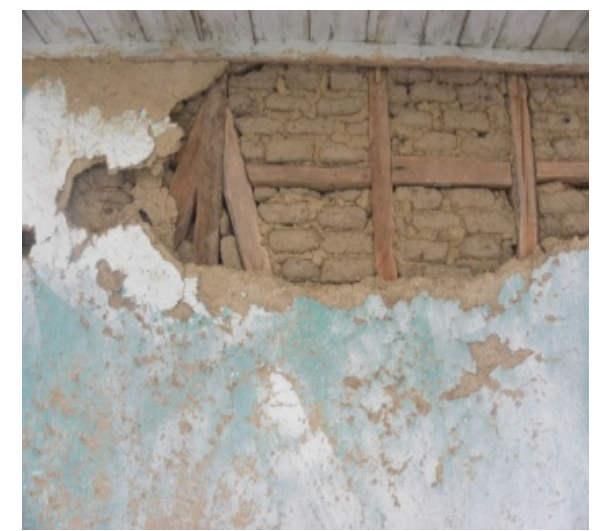

Şekil 10. Kerpiç tuğla dolgulu duvar (Fot.:Hüseyin Bayraktar)

Duvarlarda dolgu malzemesi olarak kullanılan bağdadi çıtalar 1-2 cm aralıklarla yatayda dikmelere sabitlenerek üst üste gelecek şekilde oluşturulmuştur. Daha sonra üzerilerine çamur sıva yapılmış ve sıvanın çıta aralarına girerek tutunması sağlanarak bağdadi sıva tekniği uygulanmıştır. Şekil 11 'de geleneksel köy evinin duvarında uygulanan bağdadi çıta tekniği ve bağdadi duvar örneği verilmiştir.

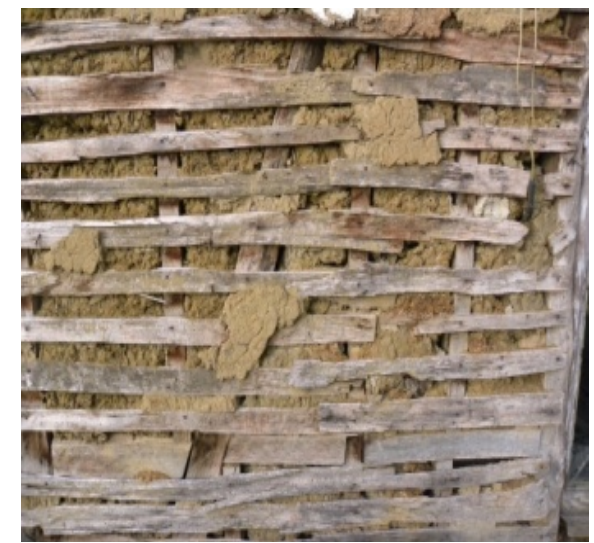

Şekil 11. Bağdadi çıta tekniği ile oluşturulmuş bağdadi duvar (Fot.:Hüseyin Bayraktar)

Ahşap karkas sistem ve duvar dolgu malzemelerinden sonra sıra duvarın kaplanmasına gelmektedir. Sadece bir ev sıvasız iken diğer tüm evler saman-toprak karışımı çamur sıva ile kaplanmıştır. Halk arasında yağlı toprak (sarı toprak) olarak nitelendirilen toprak eskiden beri yeri bilenen yerlerden özellikle dağ yamaç ve tepelerinden getirilmektedir. Sıvanın yapılmasında ve duvarın sıvanmasında kadınlar da görev almaktadır. Sıvanın yapılmasında önce bahçede $50 \mathrm{~cm}$ derinliğinde, 1 metre genişliğinde bir çukur açılır ve bu çukura yamaçlardan getirilen sarı toprak ve saman kuru karışım sonrası su ile yumuşatıır, üzeri çiğnenerek harç haline getirilmektedir. Daha sonra 1 gün dinlenen harç ertesi gün el ile duvara sıvama yapılmaktadır. Kadınlar, toprağın çiğnenmesinde ve elle sıva yapımında erkeklere yardımcı olmaktadırlar. Şekil 12'de duvarı örtmek amacıyla kullanılmış çamur sıva (saman katkılı) görülmektedir. Duvar boya malzemesi olarak ya beyaz kireç ya da doğal olarak renklendirilmiş kireç boyalar kullanılmıştır. 
Kadınlar da evlerin oluşumunda aktif rol almaktadır. Örneğin çamur sıvanın hazırlanmasında bahçede açılan bir çukurda toprağın saman ile harmanlanmasından sonra su katılarak ayaklar ile ezilmesinde, duvarın sıvanmasında ve bazı malzemelerin taşınması gibi işlerde kadınlar görev almaktadırlar. Bu sayede imece usulü tek katlı bir ev 5-10 gün gibi kısa sürede bitirebilmektedirler. Eğer ev yaptıracak ailenin maddi durumu iyi ise dışarıdan usta getirerek evini yaptırabilmektedir. Evlerin kat adedi ve büyüklüğü öncelikle aile nüfusuna göre belirlenmektedir. Büyük bir aile ise ev de büyümektedir.

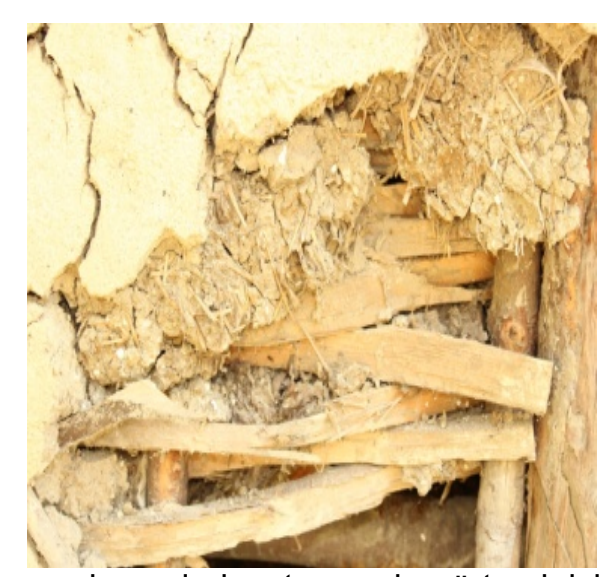

Şekil 12. Duvarda dolgu malzemeleri ve taşıyıcıları örtmek için kullanılan çamur sıva (Fot.:Hüseyin Bayraktar)

Evlerin duvarlarında genellikle ahşap, kerpiç ve taş malzemeler kullanılmışıtr. Şekil 13 'de incelenen evlerin duvarlarında dolgu malzemesi olarak kullanılan doğal malzemeler ev sayısına göre verilmiştir.

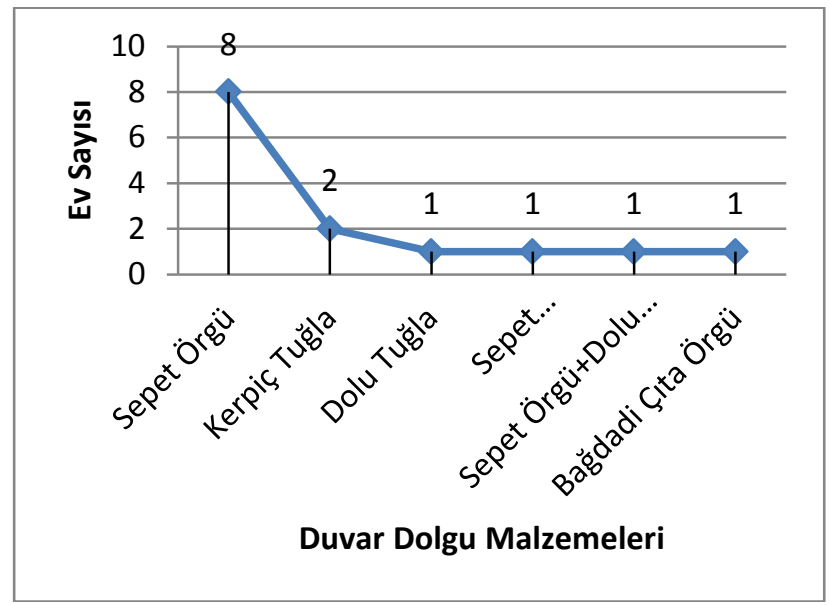

Şekil 13. Duvarlarda kullanılan doğal malzemeye göre evlerin dağılımı

İncelenen evlerin yapım tarihleri köylere göre değişmektedir. İncelenen en eski ev Kaledibi köyünde 1888 tarihinde tek katlı olarak yapılmıştır. Evin adı "Tarihi Ekrem Bey Konağı" olarak geçmektedir. Günümüzde ev aktif olarak kullanılmamaktadır. Ancak ev sahibinin kalabalık misafirleri geldiğinde kullanıma açılmaktadır. Aynı zamanda evin sahibi tarafından ev gelen konuklara gezdirilerek tanıtımı sağlanmaktadır. Ev sahibinin bu evde doğup büyümesi, evde hatıralarının olması sayesinde ev ilk günkü gibi özelliğini korumuş ve günümüze kadar yıkılmadan korunarak gelmiştir. Şekil 14'de incelenen evlerin yapım tarihleri köy yerlerine göre verilmiştir. 


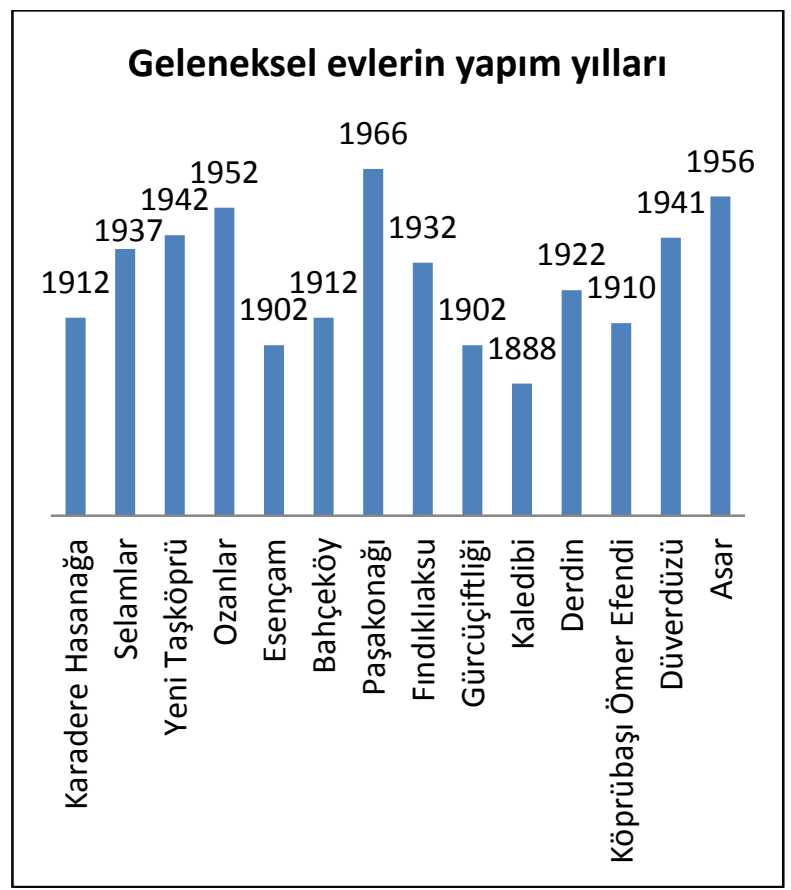

Şekil 14. Evlerin yapım tarihlerine göre dağılımları

İncelenen evlerin oturum planları genelde kareye yakındır. Bunun en önemli sebebi iç mekan plan kurgusudur. Planlamada genellikle sofa merkeze alınmakta ve sofanın etrafına odalar yerleştirilmektedir. Bu durum evlerin kare planına yakın formlarda oluşmasını sağlamıştır. Halk arasında yaşam dedikleri sofa, odaların açıldığı alan ve genelde misafir ağırlamada kullanılan bir bölümdür. Günümüzde salon olarak kullanılan alana benzer bir kullanım özelliği vardır. Sofa yazın da aktif olarak tüm aile tarafından kullanılmaktadır. Yazın havalar güzel olduğundan evde yaşayanlar ortak alan olarak sofada yiyip içmekteler, belli işleri (tütün dizimi, mısır ayıklama vb) burada yapmaktalar ve birlikte vakit geçirmektedirler. Kışın ise geleneksel tip evlerde hemen her odada bulunan ocak-gusulhane-eşya dolaplı odalarda yiyip içilmekte ve vakit geçirilmektedir. Şekil 15'de geleneksel köy evinin sofa olarak kullanılan bölümü gösterilmektedir.

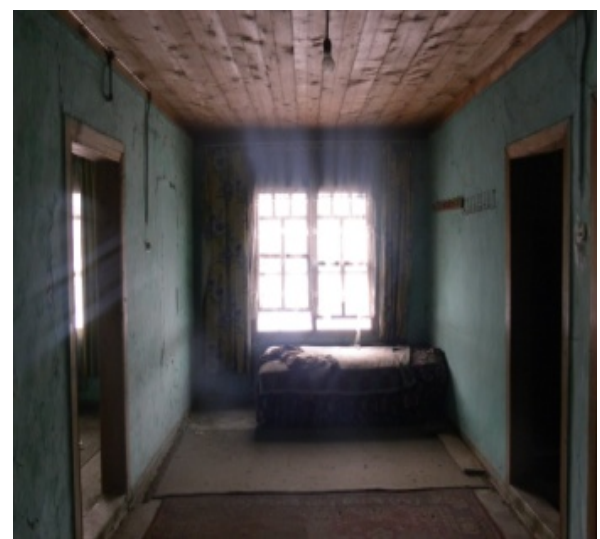

Şekil 15. Sofa olarak kullanılan ortak alandan görünüm (Fot.:Hüseyin Bayraktar)

İncelenen evlerde plan tiplerinin bir çoğu iç sofa planlı iken bir kısmı ise dış sofa planlıdır. Köyde yaşanların genelde iç sofa plan tipinde evleri istedikleri görülmüştür. Şekil 16'da evlerin plan tiplerinin oransal dağılımları gösterilmiştir. 


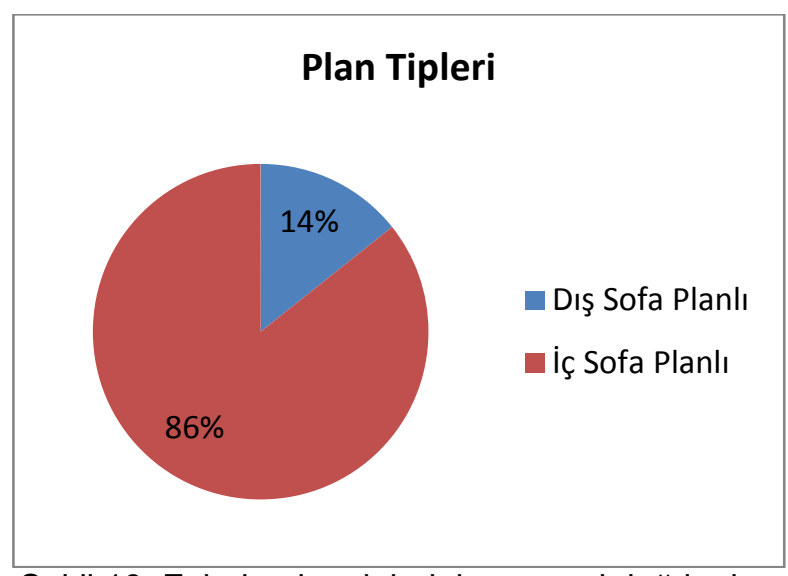

Şekil 16. Evlerin plan tiplerinin oransal dağılımları

İncelenen Geleneksel evlerin plan tipleri sofalı plan tipindedir. Sofaya aynı zamanda "hayat" denmektedir. Çünkü evde sosyal yaşam birlikteliği daha çok sofada gerçekleşmektedir. (Eldem, 1954, s.25), Türk evi plan tiplerini gelişme sırasına göre sofasız, dış sofalı, iç sofalı ve orta sofalı plan tipi olarak sıralamaktadır. Sofasız planda sofa bulunmayıp oda veya odalar yan yana dizilmek suretiyle plan oluşturulmaktadır (Şekil 17).

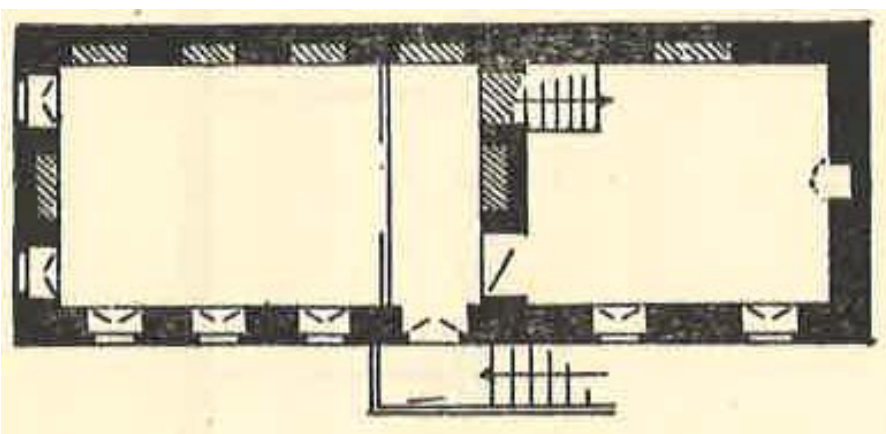

Şekil 17. Sofasız plan tipi (Eldem, 1954)

Dış sofalı planın sofasız plan tipinden sonra gelişen ilk plan tipi olduğunu belirtmektedir. Dış sofa plan tipinde odalar sofa boyunca birbirine bağlanmaktadır (şekil 18).

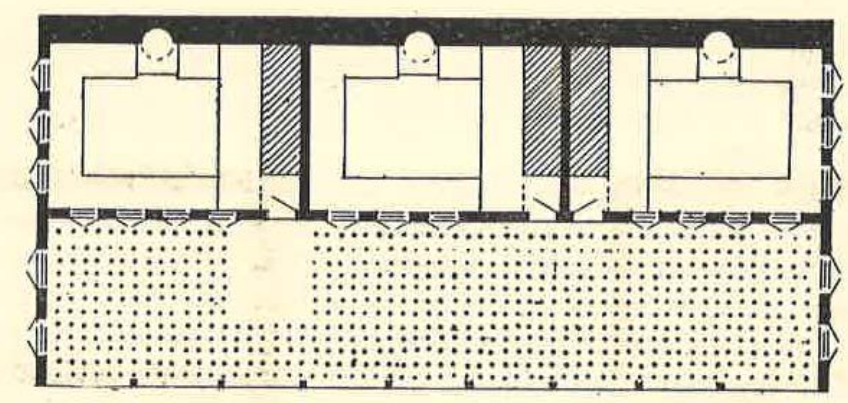

Şekil 18. Dış sofalı sıra odalı plan tipi (Eldem, 1954)

Plan tipinin ikinci aşaması iç sofalı plan tipidir. Sofanın iki yanı oda sıraları ile çevrilmektedir (Şekil 19). 


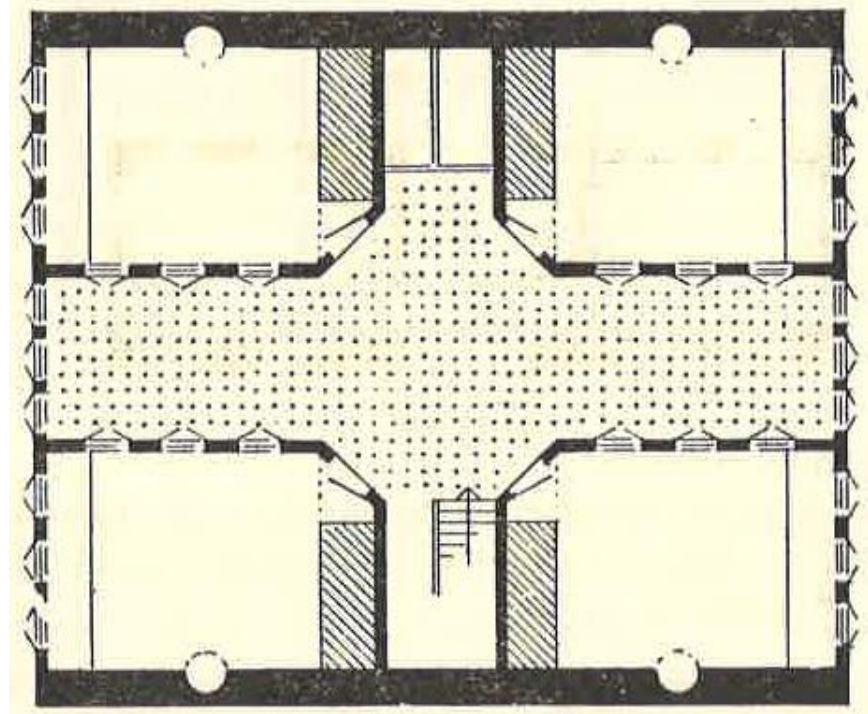

Şekil 19. İki yüzü iç sofalı ideal plan tipi (Eldem, 1954)

Plan tipinin üçüncü aşaması ise orta sofalı plan tipidir. Orta sofa planlı evde sofanın dört bir tarafı odalar ile sarılmaktadır. Evin içerisinde sofanın aydınlık kalabilmesi için oda sıralarının arasında, sofanın merkez hattında eyvan şeklinde boşluklar bırakılmaktadır. Sofaya açılan eyvan sayısı birden dörde kadar artırılması bu plan tipinin en zengin betimlemelerini meydana getirmektedir orta sofa veya merkezi tip, en çok İstanbul'da uygulanmıştır (Şekil 20).

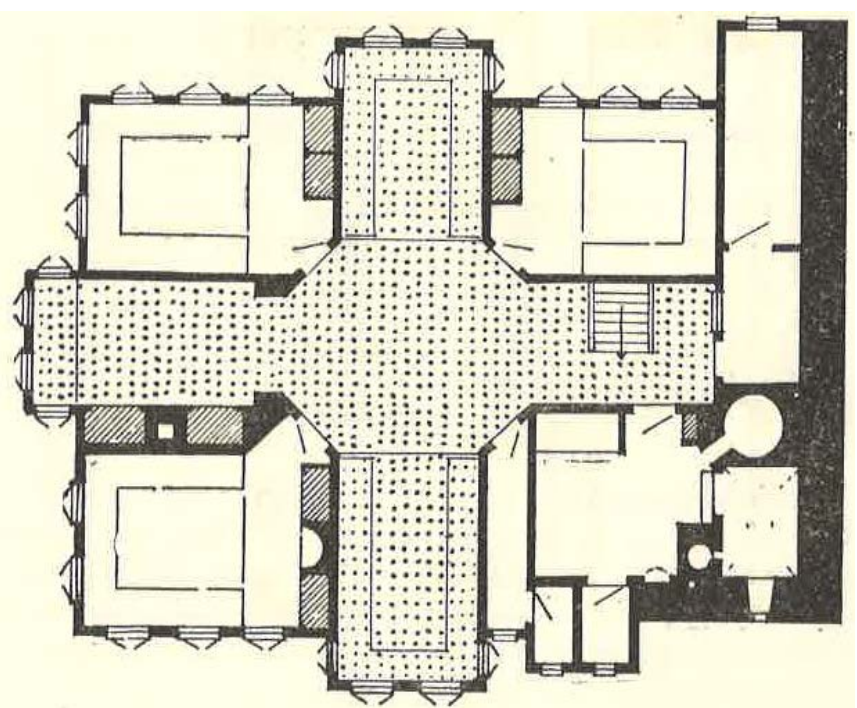

Şekil 20. Sofanın üç istikemette eyvanları, bir de merdivenli yan sofası bulunan orta sofa planlı ev (Eldem, 1954)

İncelenen geleneksel evlerden Köprübaşı Ömer Efendi Köyünde bulunan eve ait dış sofa plan tipinde örnek şema çizilerek şekil 21'de verilmektedir. Evde aynı ölçülerde iki ocaklı oda sofanın bir yanağı boyunca uzanmaktadır. Diğer iki odaya göre daha küçük bir oda ise sofanın merkezine bakacak şekilde konumlandırılmış, günümüzde oda hem oturma hem de mutfak olarak kullanılmaktadır. Odalardan dış sofaya kapılar açılmaktadır. Bahsi geçen evde zamanında iki ailenin yaşadığı belirtilmiştir. 


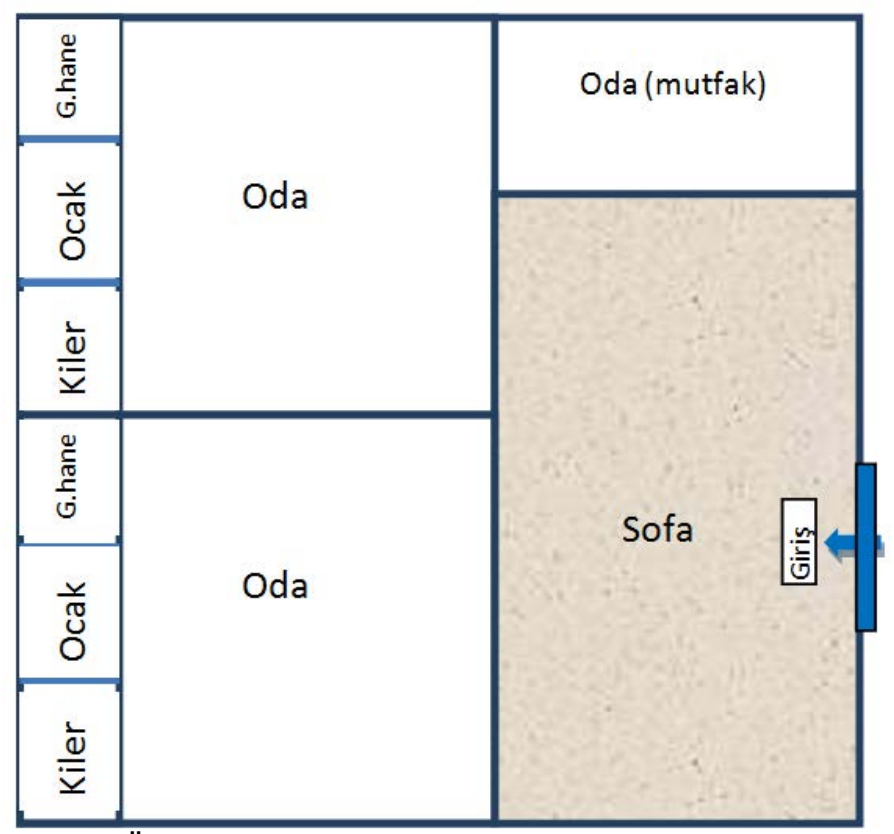

Şekil 21. Köprübaşı Ömer Efendi Köyü dış sofa planlı geleneksel ev örneği şeması

İncelenen bir diğer geleneksel ev ise Kaledibi Köyünde bulunmaktadır. Evin ismi Ekrem Bey Konağı olarak anılmaktadır. Evin sahipleri evi ilk haliyle korumaya çalışmaktadır. Dışarıdan gelen ziyaretçilere evin tanıtımı yapılmaktadır. Evde zamanında 12-13 kişinin bir arada kalabildiği belirtilmiştir. İç sofa plan tipindeki evde iki ocaklı ve iki ocaksız oda olmak üzere toplamda 4 oda bulunmaktadır. Şekil 22'de Kaledibi Köyünde incelenen eve ait iç sofa plan tipinde örnek şema verilmektedir.

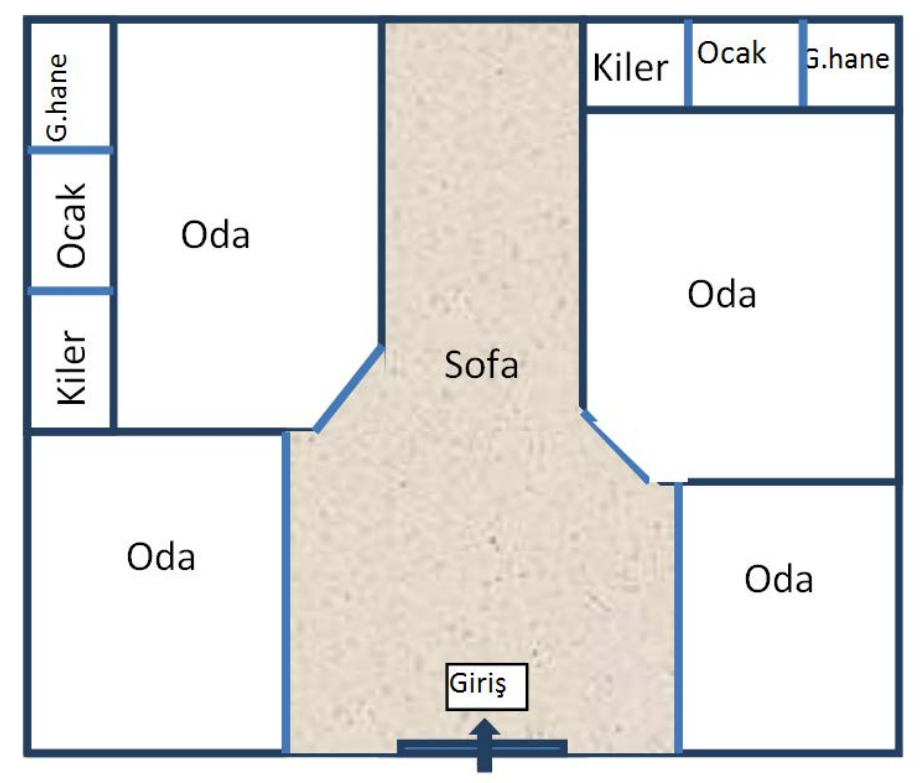

Şekil 22. İç sofa planlı geleneksel ev örneği, Ekrem Bey Konağı, Kaledibi

İncelenen evlerin yönlendirilmeleri genellikle güney kuzey yönündedir. Evin yönlendirmesi ile ilgili soruya yöre halkı tarafından kıble yönlü diyerek cevap verilmektedir. Yani kıble yönlü derken evin girişi kıbleye bakacak şekilde güney cepheli olarak konumlandırılmaktadır. Burada evlerin konumlandırılmasında inanç faktörünün ön planda tutulduğunu söylemek mümkündür. Şekil 23'de kıble yönüne baktığı belirtilen geleneksel köy evi verilmiştir. 


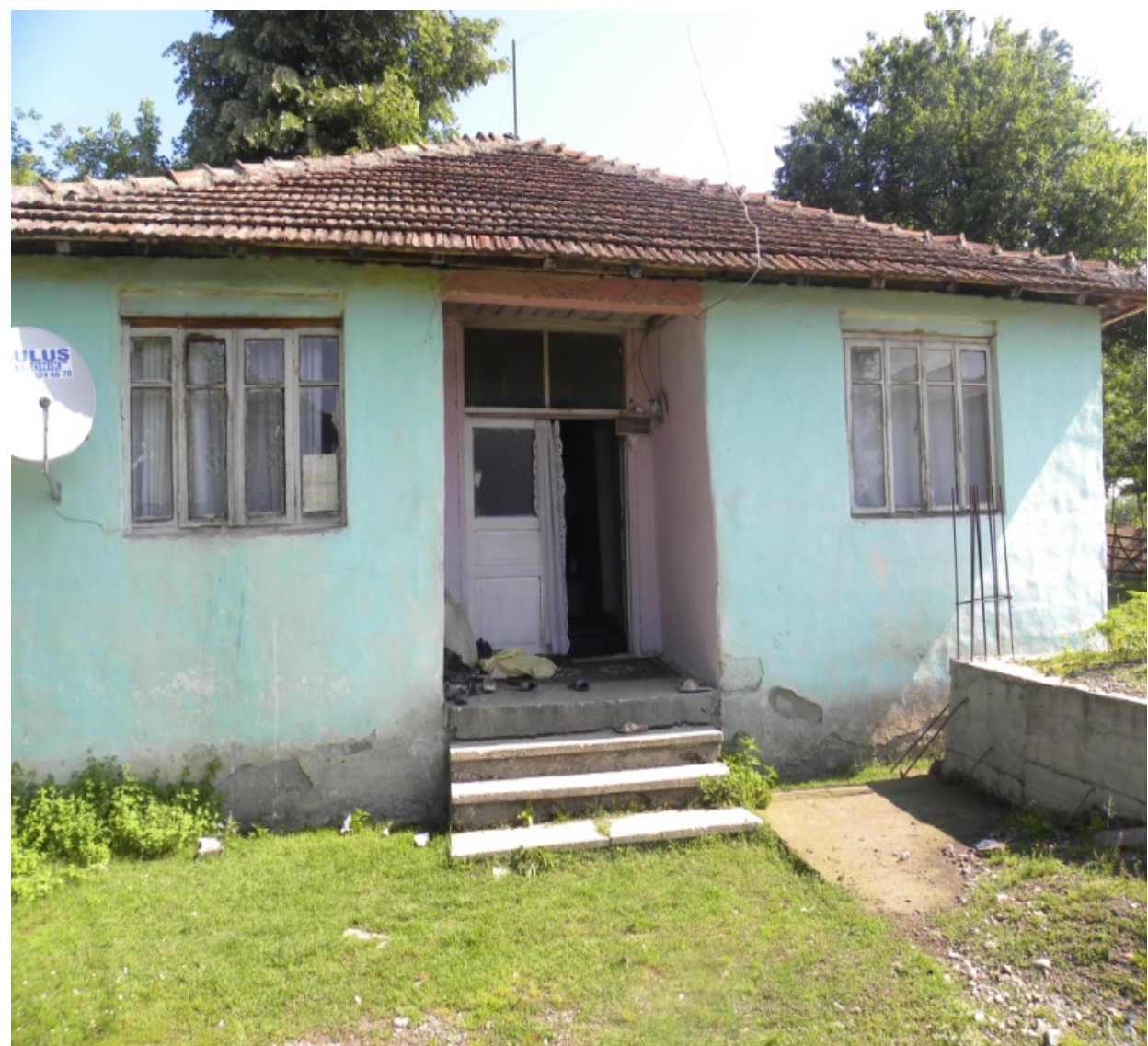

Şekil 23. Kıble yönlü bir köy evinden görünüm (Fot.:Hüseyin Bayraktar)

Geleneksel köy evlerinin bahçe içerisinde konumlandırılmalarında farklıııklar bulunmaktadır. Eğer bahçe kullanımı önemli olacak ise yani bahçede domates, biber, meyve ağaçları vb yetiştirilmesi düşünülüyor ise ev bahçenin başına yapılmaktadır. Bu sayede bahçeden tarımsal olarak daha fazla faydalanılmaktadır. Bahçe içerisinde hayvan barınağı yapılacak ise bu durumda ev bahçenin biraz daha ortalarına doğru yapııırken hayvan barınağı da hemen arkasına yapılmaktadır. Ayrıca çoğu evin bahçelerinde yemek pişirmek, ekmek yapmak vb için kullanılan fırınlar yapılmaktadır. İncelenen köylerde bahçede yer alan pişirme için kullanılan yerlere fırın denmektedir. Fırınlar özellikle kalabalık ailelerde çokça kullanılmaktadır. Aynı zamanda köyde birinin düğünü olduğunda ya da bayramlarda fırında birçok kişiye yetecek yemekler, ekmekler yapılmaktadır. Fırınlar evin rutin işlerinde kullanıldığı gibi birlikte yeme-içme paylaşımı sağlayan sosyal bir görev üstlenmektedir. Şekil 24'de bahçe içerisinde konumlarılan fırın ve ev ilişkisi gösterilmektedir. Bazı evlerin bahçelerinde kışlık yiyeceklerin, evde ya da tarlada vb kullanılacak aletlerin konulduğu bir depo yapılmaktadır. Depo yaz kış kullanılan önemli bir müştemilat olarak bahçede yerini almaktadır. Bazı evlerin bahçelerinde kuyular bulunmaktadır. Bu kuyular evin yaklaşık 5-10 metre yakınında açılıp içerisi moloz taşlar ile örülmektedir. Kuyular yazın içme suyu ya da bahçelerin sulanması gibi işlevlerinin yanında eskiden buzdolabının olmaması yemeklerin çabuk bozulmasına neden olduğundan kuyular soğutucu olarak da kullanılmıştır. Kuyunun üzerine bir tahta uzatılarak ortasından ip bağlanmaktadır. İpin ucuna bağlanan ve içerisinde süt, yoğurt, yemek vb bulunabilen kaplar kuyu suyuna yakın bir yere kadar indirilerek kuyunun içerisinde bekletilmektedir. Kuyunun içi yaz sıcağında dahi serin olduğundan yiyecekler daha uzun süre bozulmadan kalabilmektedir. Bahçede yer alan barınak, depo, fırın, kuyu gibi yapılar ev ile bir bütünlük sağlamaktadır. İncelenen 
evlerin hemen hepsi bahçe içerisinde yapılmış ve evlerin bahçelerinde evin günlük işlerine yardımcı küçük yapılar muhakkak bulunmaktadır. Ev, bahçe içerisinde planlanırken etrafında gerekli tüm yardımcı yapılar da planlanmaktadır. Çünkü geleneksel köy evlerinde hayatın sürdürülmesi, zor yaşam şartlarının kolaylaştırıması gibi işlevler ön plana alınmaktadır.

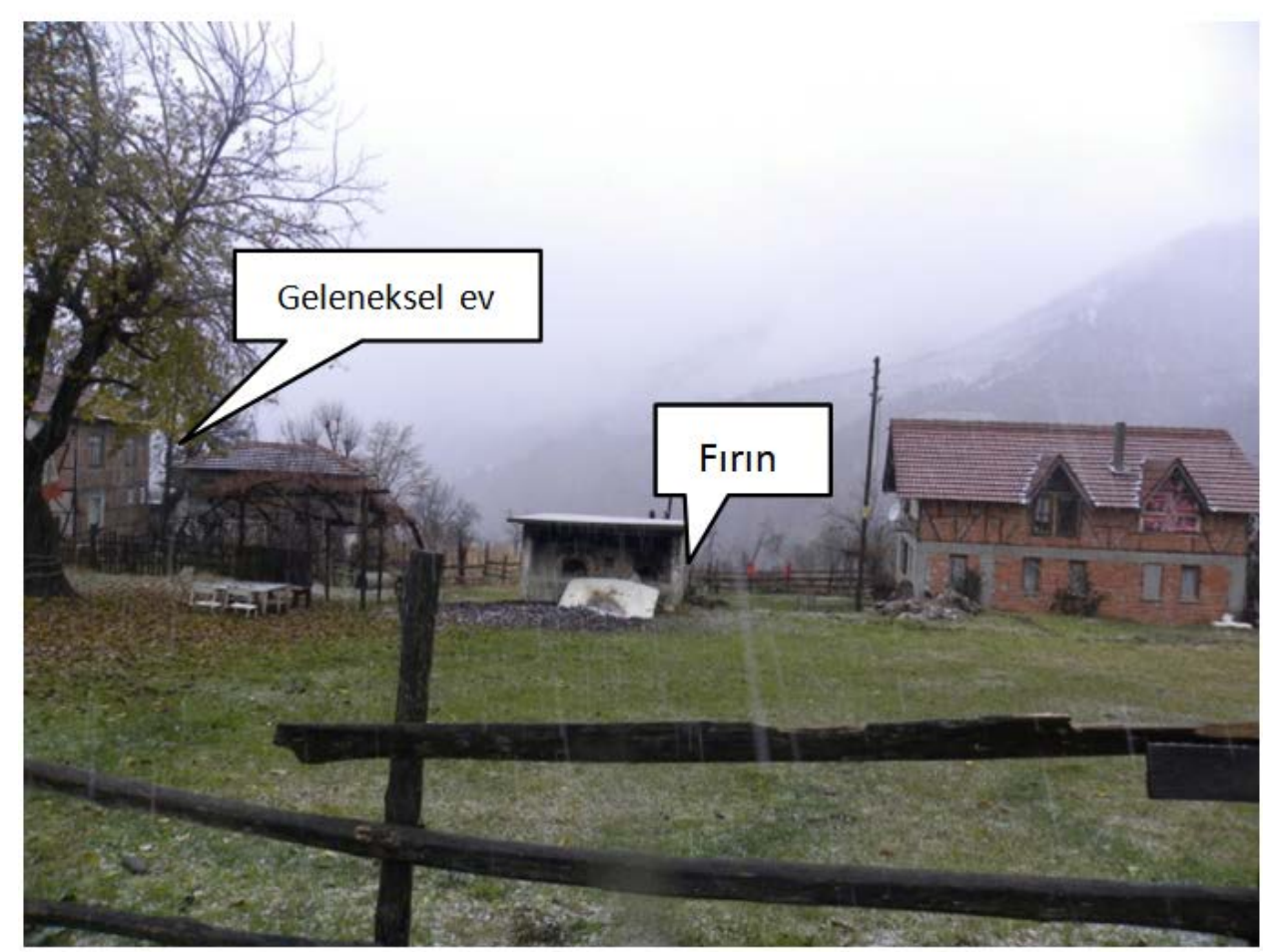

Şekil 24. Geleneksel ev ve fırının bahçe içerisindeki konumu, Düverdüzü köyü (Fot.:Hüseyin Bayraktar)

Incelenen evlerin tamamı mesken olarak planlanmıştır. Köylerden kente göç edilmeden önce evlerin tamamı aktif olarak kullanılmıştır. Fakat köylerin nüfus kaybetmesi ve yeni modern mimariye yönelimin artması geleneksel köy evlerinin kullanım oranını düşürmüştür. Örneğin incelenen evlerden yarısı (7 adedi) aktif kullanılıyorken geriye kalan diğer yarısı (7 adedi) oturum amaçlı kullanılmayıp boş bir halde kaderlerine terk edilmiş haldedir. Şekil 25 'de evlerin mesken olarak aktif ve pasif kullanım oranları verilmektedir.

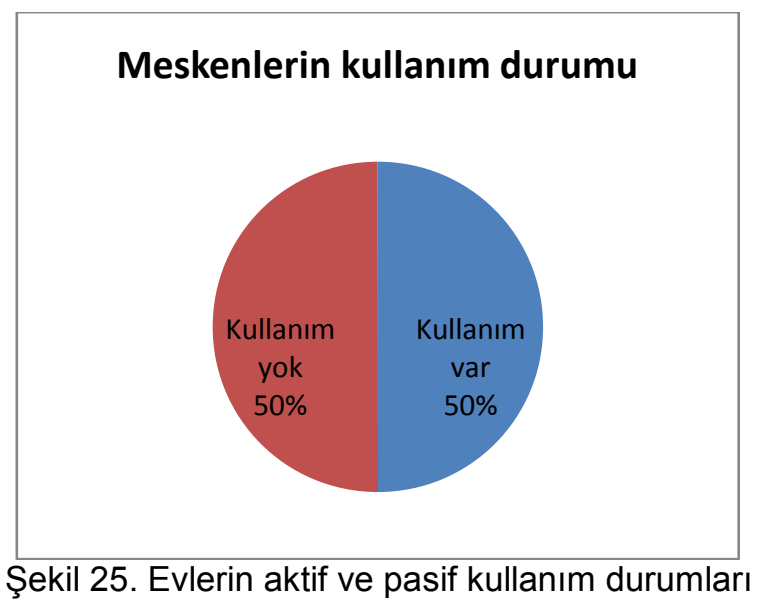


Köy işlerinin yoğun olması insana duyulan gereksinimi de artırmaktadır. Bu yüzden geleneksel köy evleri planlanırken geniş ailelerin yaşayabileceği biçimde planlanmıştır. Incelenen evlerde yaşam mekanları olarak kullanılan oda sayıları 3 ila 8 arasında değişmektedir. Şekil 26'da incelenen köy evlerinin sahip oldukları oda sayıları gösterilmektedir.

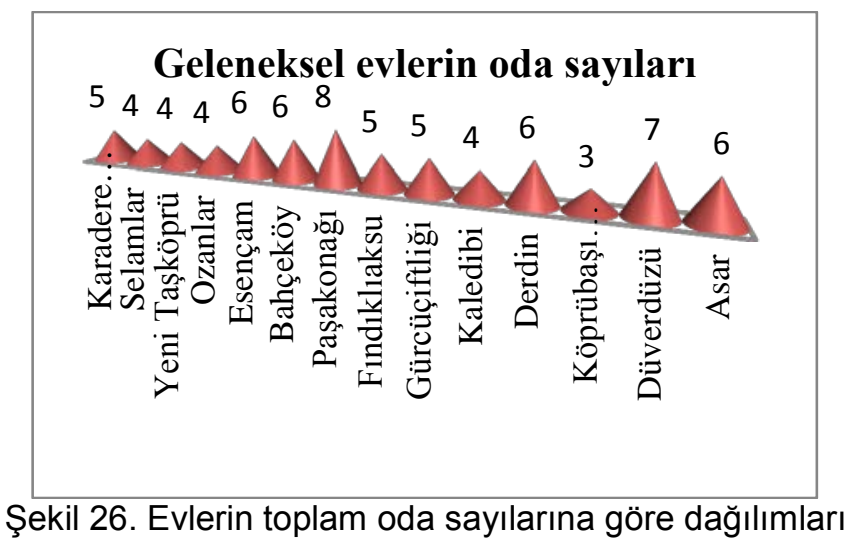

\subsection{Incelenen evlerde önemli bir iç mekan kurgusu; ocaklı odalar}

Odalar tasarlanırken bir ailenin temel intiyaçları düşünülerek tasarlanmaktadır. Aile içerisinde evlenen birey yeni ailesiyle birlikte temel ihtiyaçlarının çoğunun görülebildiği ev içerisinde ocaklı oda olarak planlanan yerde kalmaktadır. Bu sayede birden fazla aile aynı evde yıllarca yaşamaktadır.

Odalarda aydınlığına önem verilerek iki cephede pencere yeri bırakılmaktadır. Odaya giriş kapısının hemen arkasında yer alan cephede üçlü çözümleme ocak gusülhaneyüklük yapılmaktadır. Ocak, yüklük ve gusülhanenin ortasında yer almaktadır. Yüklük (eşya dolabı) oda kapısının arkasında, gusülhane ise dış cephe duvarına bitişik yapılmaktadır. Yüklük ahşap malzemeden müteşekkil yerden tavana kadar uzanan bir dolaptır. Yüklük içerisinde tabak, çanak, ibrik, giysi, yatak-yorgan gibi malzemeler konulmaktadır. Genelde yüklüğün en alt bölmesinde (buraya halk arasında "izbe" denmektedir) ocakta yakılacak odunların bulunduğu izbe gözü yer almaktadır. Gusülhane (halk arasında yıkanmalık/hamam dolabı) ise banyo yapma, tabak, çanak, giysi gibi eşyaların yıkanmasında kullanılmaktadır. Evlerde genelde odalar ocaklı olduğundan bir aile bir odada rahatlıkla yaşayabilmektedir. Ocaklı oda içerisinde sofaya bakan camlı bölme (niş) önüne konan gazlı lamba, hem odayı hem de sofayı aydınlatmada kullanılmaktadır. Odalarda bulunan ocaklar sayesinde ısınma, yemek pişirme, yıkanma gibi temel intiyaçlar gerçekleştirilmektedir. Bu sayede 1 katlı evlerde 10-12 kişi, 2 katlı evlerde ise 15-17 kadar kişinin yaşadığı yöre halkı tarafından belirtilmektedir.

Şekil 27'de kullanımı devam eden bir evin ocak-gusülhane-yüklük üçlüsünün bir arada olduğu fotoğraf gösterilmektedir. Şekil 28'de ise kullanılmayan bir evden ocak, iç kısımlarının görünmesi amacıyla kapakları açılmış yüklük ve gusülhaneden görünüm verilmiştir. Şekil 29'da ocaklı odanın gusülhane, ocak ve yüklük (kiler) görünüş çizimi yapılmıştır. 


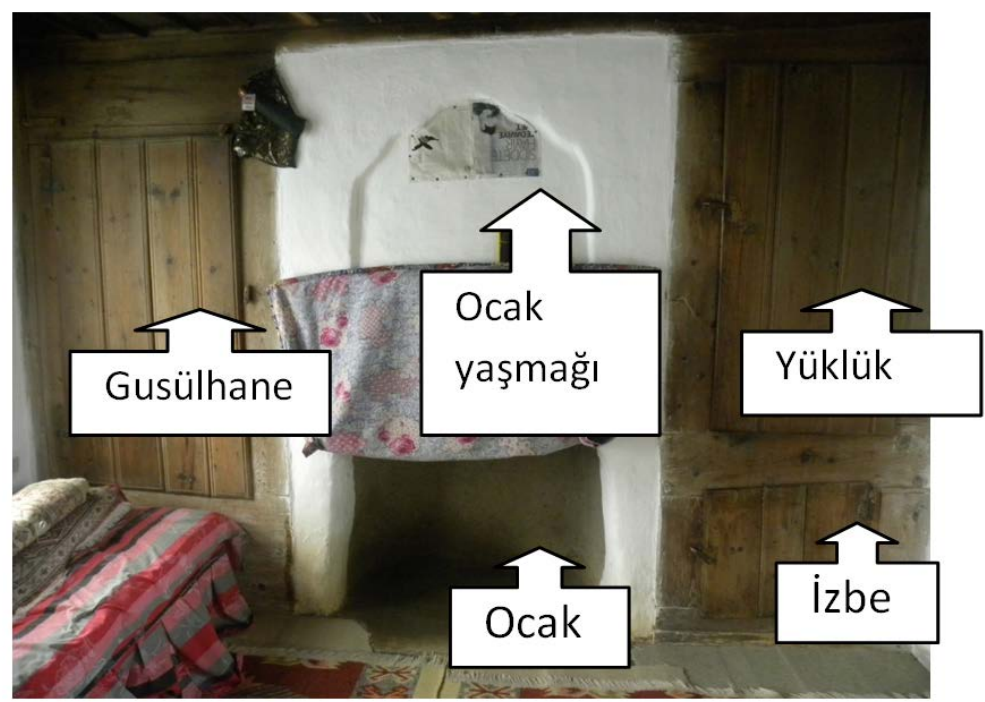

Şekil 27. Aktif kullanılan bir evin yaşam mekanı olarak kullanılan odasında ocak, gusülhane ve yüklük üçlüsü (Fot.:Hüseyin Bayraktar)

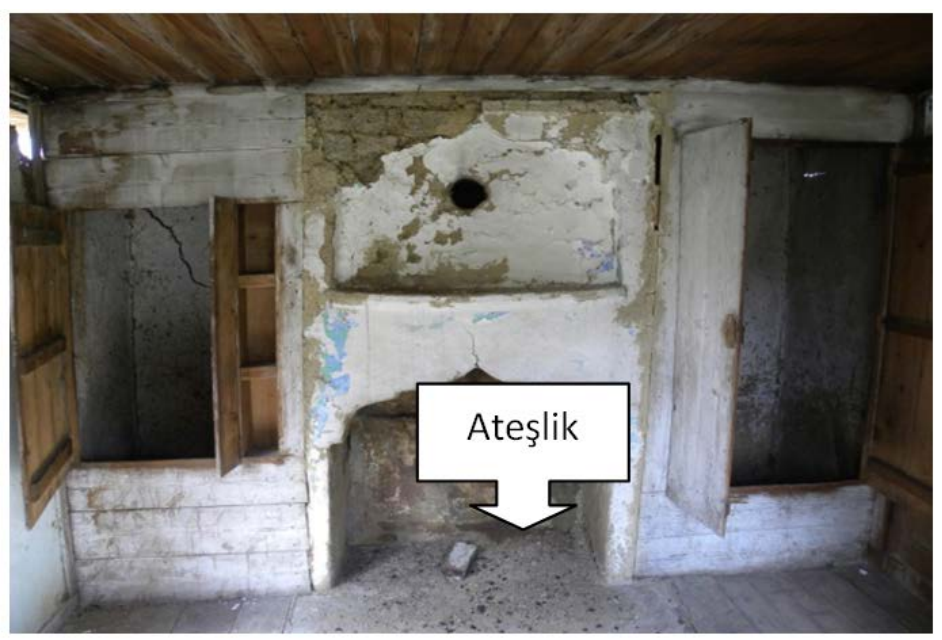

Şekil 28. Pasif durumda kullanılmayan bir evin ocak, gusülhane ve yüklüğün görüntüsü (Fot.:Hüseyin Bayraktar)

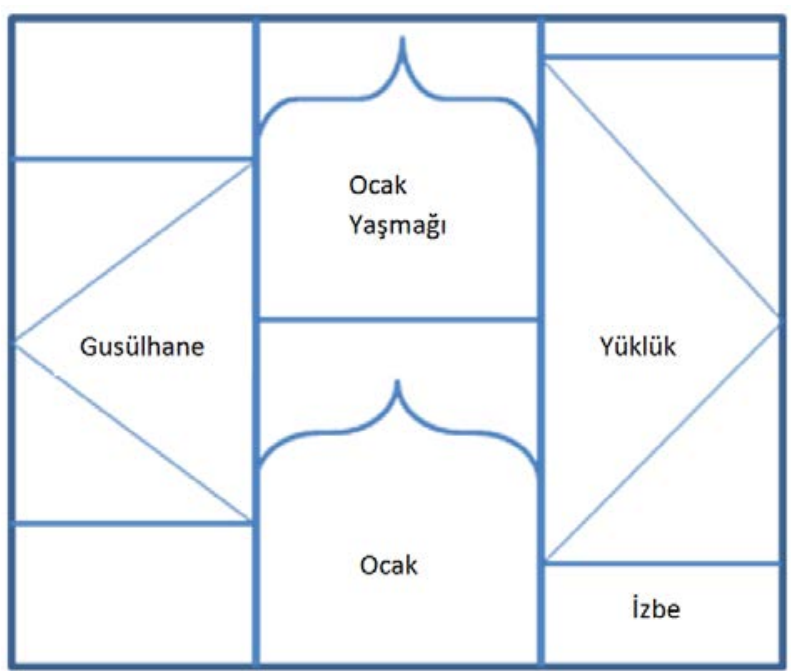

Şekil 29. Ocaklı oda gusülhane, ocak ve yüklük (kiler) görünüş çizimi 
Yaşam mekanı olarak kullanılan odalarda işlevsellik ocak merkezli gelişmiştir. Çünkü ocakta yemek pişirilir, banyo için su kaynatıır, odanın ısınması sağlanır. Yani ocak temel fonksiyonların sürdürülmesinde hayati bir öneme sahiptir. Servis mekanı olarak kullanılan örneğin mutfakta kullanılan ocak ise evde bulunan herkes için ortak amaçlı kullanılmaktadır. Mutfakta toplu yemek yapılmadığında yaşam mekanı olarak kullanılan odalarda her aile kendisi yemeğini ocakta yapmaktadır. İncelenen evlerde ocağın üst kısmını örtmek ve estetik bir görünüm vermek amacıyla ocak yaşmağı yapılmıştır. Ocağın ateşliği yer tabanı ile aynı seviyededir. Ocağın iç kısımda duman tahliye bacası temel zemini tabanından çatıya kadar çıkmaktadır. Bacanın üst bölümünü taşıyan temel tabanına denk gelen kısmı moloz taşlardan, katlara denk gelen kısımları ise kerpiç tuğlalardan örülmektedir. Şekil 30'da moloz taşlarla örülü bacanın en alt bölümü gösterilmektedir.

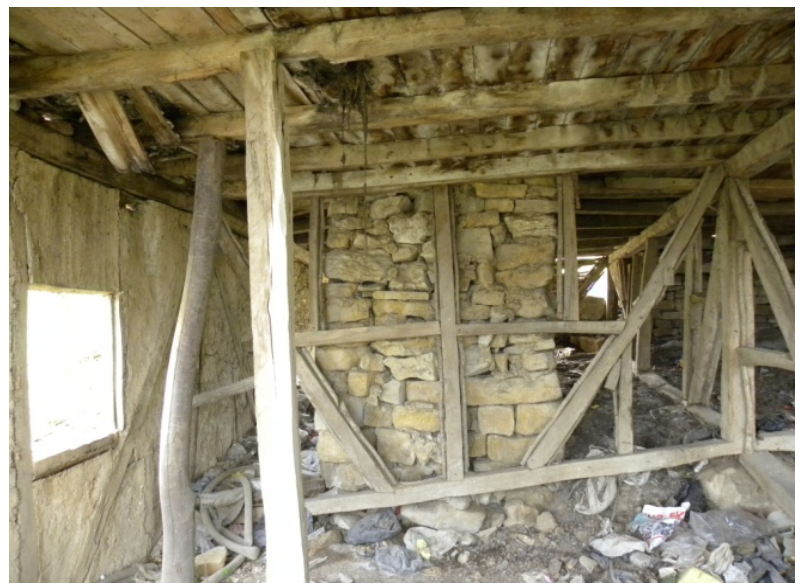

Şekil 30. Ocağın temeli moloz taş örgülü (Fot.:Hüseyin Bayraktar)

Bunun nedeni ahşap yapı içerisinde bacayı izole ederek yangına sebebiyet vermemektir. Temel zemini kısmında moloz taşlardan örülen baca moloz taş temeli bir üst kata çıktığında taşların üzeri toprak ile örtülmektedir. Şekil 31'de tabanı toprak ile kapatılmış ve üzeri ocak yapımına hazır hale getirilmiş bölümün fotoğrafı yer almaktadır.

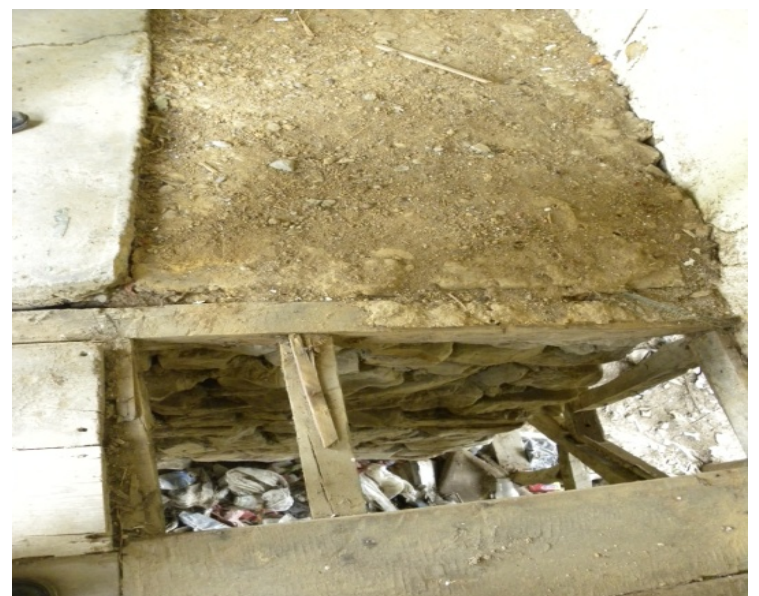

Şekil 31. Ocak temel taşlarının bittiği yer toprak örtülü, üstten görünüm (Fot.:Hüseyin Bayraktar)

Bundan sonra bacanın çatıya kadar olan kısmı kerpiçten yapılmaktadır. Kerpiç yanmaz malzeme olduğu için bacaların yapımında tercih edilmiştir. Ocağın ateşlik bölümleri daha geniş tutulurken (ocak genişliği ile aynı $140 \mathrm{~cm}$ ) üste doğru çatıya çıktıkça bacanın tahliye bacası azalarak çatıda $60 \mathrm{~cm}$ çapa düşmektedir. Şekil 32'de bacanın ateşlikten çatıya kadar olan bölümü görülmektedir. 


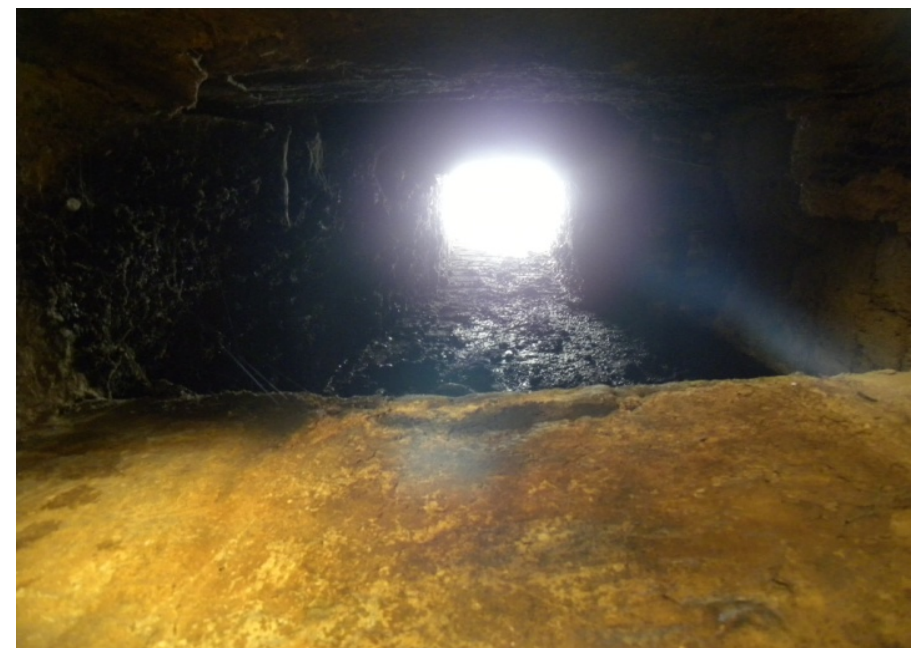

Şekil 32. Ocağın ateşlik kısmından çatıya doğru baca çapının daralması (Fot.:Hüseyin Bayraktar)

Evlerin yapımında malzemeden teknik uygulamaya kadar her türlü detay düşünülmüştür. Örneğin ahşap malzeme ağırıklı bir evde aynı anda birden fazla ocak yakılabilmektedir. Fakat ocaklar evin ahşap aksanına herhangi bir zarar vermemektedir. Evlerin plan kurgularında ortak yaşam alanlarına çıkış vardır. Evlerde kullanılan doğal malzemeler sayesinde iç ortamlarda konfor yakalanabilmiştir. Teknik olarak evlerin yapımı temel taşından başlayıp çatı planına kadar coğrafi özelliklere ve malzemelerin çevresel uygunluğuna göre en uygun tekniklerde yapılarak uzun yıllar kullanılabilirliğini sağlamıştır.

\subsection{Evlerin ahşap malzemelerinin ve mimari detayların elde edilmesinde kullanılan basit el aletleri}

Köylerde incelenen evlerin yapımında ana malzeme olarak ahşap kullanılmıştır. Ahşap malzemenin kullanılacağı yere göre ormanlık bölgeden ağaç türü tercih edilmektedir. Evlerin çatısında, döşemesinde, dikme ve çaprazlarda taşıyıcı olarak kullanılan ahşap malzemeler genelde meşe, göknar, kayın, kestane, çam gibi sağlam ve uzun süre dayanabilen ağaçlardan elde edilmektedir. Ağaçlar çoğunlukla kışın ağacın öz suyunu toprağa verdiği zamanlarda kesilmektedir. Ağaç sonbaharda öz suyunu toprağa vererek bakteri, mantar ve zararlı böceklerden korunabilmektedir. Kışın kesilen ağaçlardan elde edilen keresteler mantar, bakteri gibi mikro organizmalardan ve böceklerden korunarak uzun süre dayanım gösterebilmektedir. Ormandan kesilerek getirilen ağaçlar evin inşaatında kullanılmak üzere kerestelere ayrılmaktadır. Dikmelerde ve çaprazlarda kullanılacak ahşap malzemeler kare ya da kareye yakın kesilmekte (genelde $5 \times 10 \mathrm{~cm}, 10 \times 10 \mathrm{~cm}$ boyutlarında), döşemede kullanılacak ahşap malzemeler ise yassı bir biçimde (genelde $5 \times 15 \mathrm{~cm}, 5 \times 20 \mathrm{~cm}, 5 \times 25 \mathrm{~cm}$ boyutlarında) kesilmektedir. Ağaç tomrukların biçilmesinde yani keresteler haline getirilmesinde el hızarı kullanılmaktadır (Şekil 33). Hızarın büyük tomrukları rahatlıkla kesmesi için yaklaşık bir insan boyunda ahşap malzemeden yapılmış tezgah kurulmaktadır. Hızarın iki yanının geniş olmasının nedeni tomruğun hızar içerisine rahat sığarak kesintisiz kesilmesini sağlarken ön kısımlarında yapılan tahtalar ise iki tarafından kişilerin tutmasını sağlamaktadır. Tezgahın üzerinde bir kişi ve aşağıda bir kişi hızarı aşağıyukarı hareket ettirerek tomrukları parçalara ayırmaktadır. Zahmetli ve yorucu olan bu iş sonunda büyük tomruklar istenen düzlükte, biçimde ve ölçüde kesilerek keresteler haline getirilmektedir. Elde edilen keresteler evin farklı bölümlerinde ahşap malzemesi olarak kullanılmaktadır. 


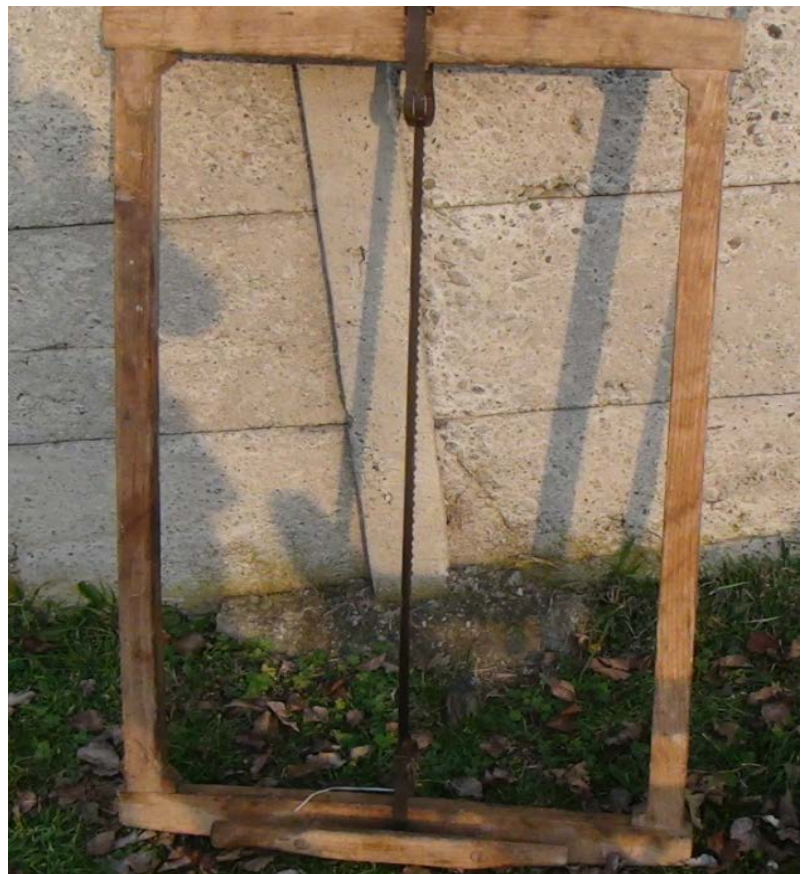

Şekil 33. Ağaç tomrukların kereste haline getirilmesinde kullanılan el hızarı (Fot.:Hüseyin Bayraktar)

Tezgah kurulmadan tomruk, kütük, tahta gibi malzemeleri bölmede kol bıçkıları kullanılmaktadır. Kol bıçkıları tek kişinin rahatııkla kullanılabileceği basit el aletlerindendir. Şekil 34'de ortada hızar hemen iki yanda kol bıçkıları görülmektedir.

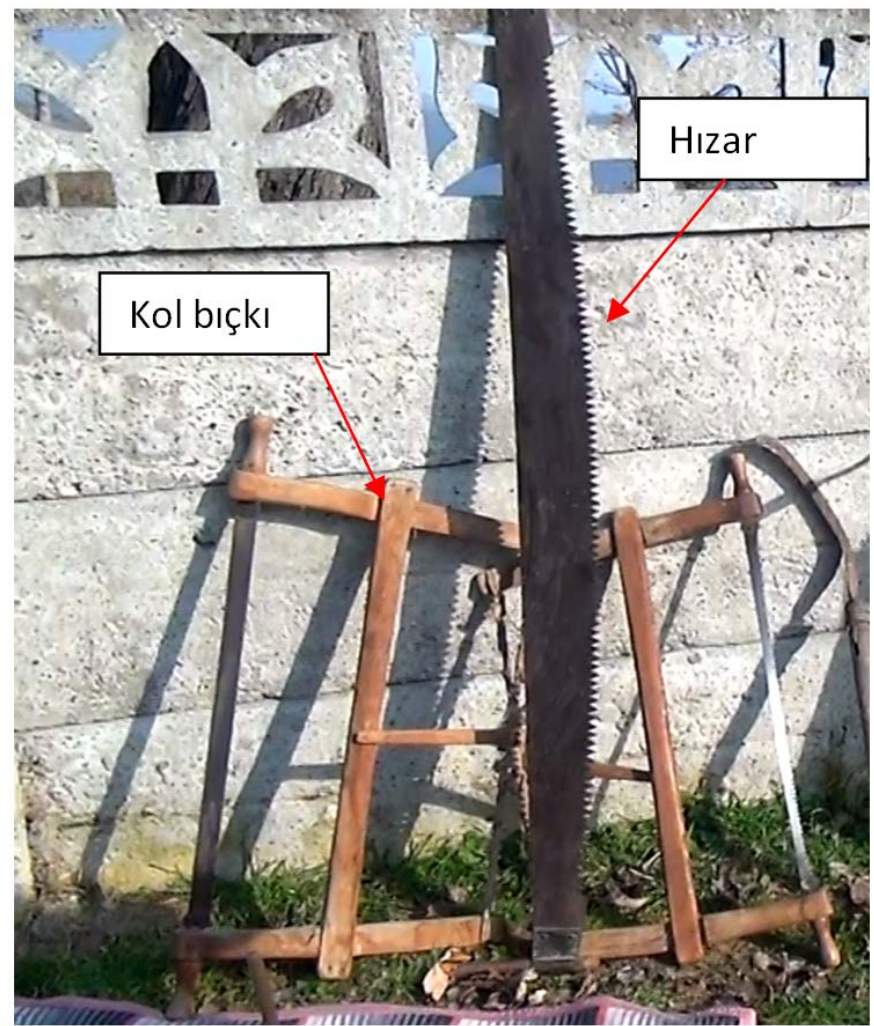

Şekil 34. Ahşap elemanların kesiminde kullanılan kol bıçkıları (Fot.:Hüseyin Bayraktar) 
El testeresi, kol bıçkıları, el hızarı ile tomruklar istenilen boyut ve şekillerde ahşap malzemelere dönüştürülebilmektedir. Ağaçların budanması, keresteler haline getirilmesi, sivri ahşap kazıkların elde edilmesi gibi işlerde kullanılabilen balta, nacak vb metal elemanların keskin olması (bilenmesi) için taş çarklar kullanılmıştır. Taş çarka yöre halkı "kösele" demektedir. Taş çarkın bileme işini yapan daire kesitli sert kayanın ortasından delik açılıp içinden daire kesitli bir metal demir geçirilerek uzunlamasına iki ahşap malzeme arasına dönebilecek şekilde yerleştirilmektedir. Taş çarkın ortasındaki metal demire el ile çevrilebilecek bir metal bağlanmaktadır. Bu şekilde taş çark elle döndürülürken bir taraftan üzerine su dökülerek balta, nacak gibi keskin olması istenen aletler bilenmektedir. Şekil 35'de taş çarkın kullanım anını gösterir fotoğraf görülmektedir.

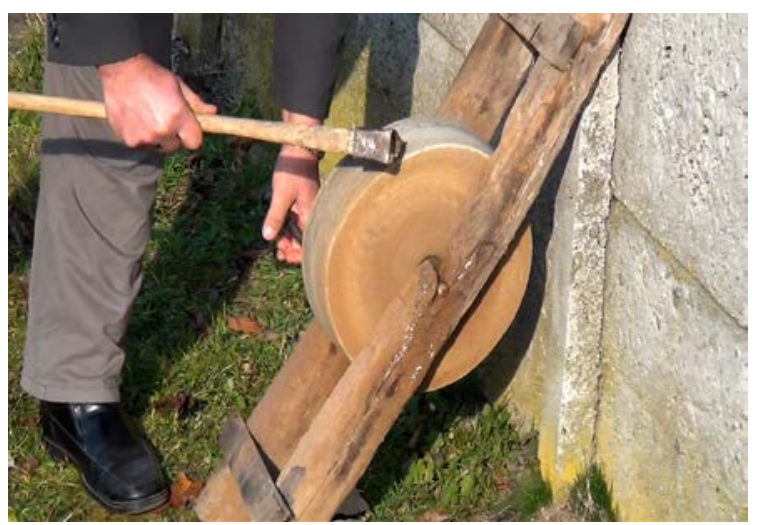

Şekil 35. Balta, nacak gibi aletlerin bilinmesinde kullanılan taş çark (Fot.:Hüseyin Bayraktar)

Incelik ve detay isteyen malzemelerin elde edilmesinde kullanılan marangozluk aletleri Evlerin ahşap malzemelerinin belli parça ve boyutlarda kereste olarak elde edilmesinden sonra hassas ve detay isteyen işlerde farklı marangozluk aletleri kullanılmaktadır (Şekil 36). Bu aletler evin yapısal malzemelerinde, süslemelerinde ve hatta evin mutfak eşyalarının elde edilmesi de dahil çeşitli ahşap ürünlerin elde edilmesinde kullanılabilmektedir. Zamanında ahşap malzemelerin elde edilmesinde motorsuz el aletlerinin kullanımı yoğunken günümüzde bu malzemelerin yerini geliştirilmiş motorlu aletler almıştır.

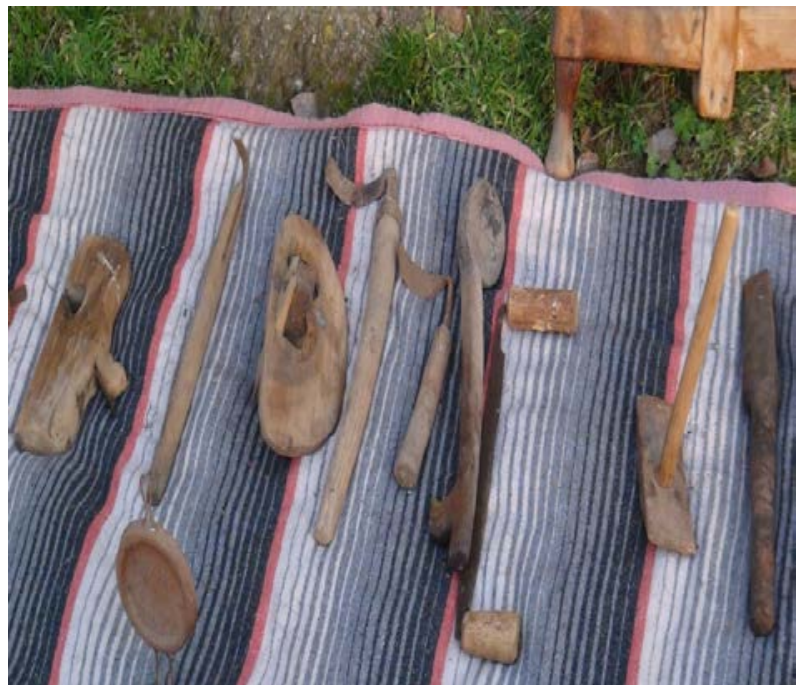

Şekil 36. Marangozluk işlerinde kullanılan basit el aletleri (Fot.:Hüseyin Bayraktar) 
Hızarlar ile kesilen tomruklar kerestelere ayrıldıktan sonra ahşap malzeme üzerinde düzleştirme, rendeleme gibi işler başlamaktadır. Ahşap düzeneğinin içerisinde yer alan metal bıçak sayesinde rendeleme, düzleştirme işlerinde "düztaban" denen rende aletleri kullanılmaktadır. Rende aletleri ile düz yüzeyli ya da geçmeli ahşap malzemeler elde edilebilmektedir. Şekil 37'de üç adet düztaban (ahşap rende) verilen fotoğrafta soldan ilk sıradaki kısa ahşap rende ahşabın düzleştirilmesinde, ortadaki kısa ahşap rende ahşap malzemelerin birbirine geçmesini sağlamak için lamba-zıvana geçme yerinin açılmasında ve uzun olan ahşap rende ise ahşabın kıyım işlerinde kullanılmaktadır.

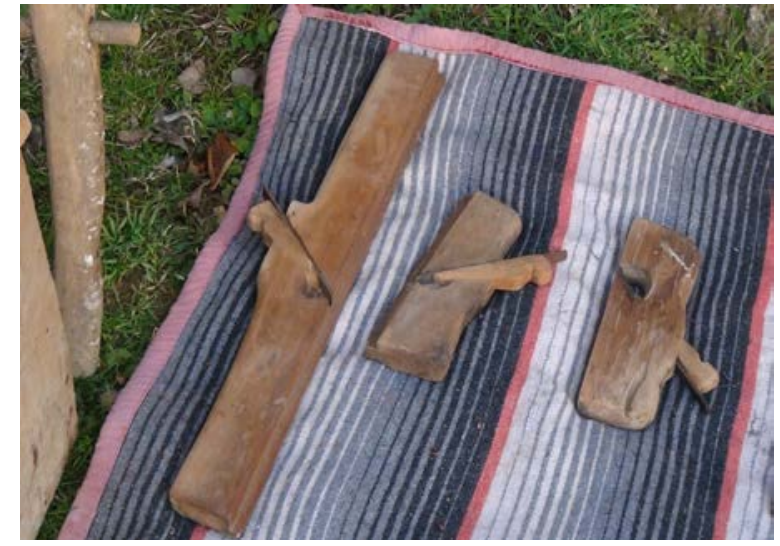

Şekil 37. Kerestelerin düzleştirilmesi ve rendelenmesinde kullanılan basit el aletleri, düztaban (Fot::Hüseyin Bayraktar)

Ağaç tomruktan küçük boyutlara getirilen ahşap malzemelere ince işçilik gerektiren oval detaylar verilmek istendiğinde yontma ve oymada kullanılan basit yontma el aletleri (iç bıçakları) kullanılmaktadır. Şekil 38'de fotoğrafın sağ bölümünde oyma işlerinde kullanılan iç bıçaklarından farklı metal uçlara sahip üç adet iç bıçağı ve solda iç bıçakları ile yontularak hazırlanmış bir ahşap kaşık bulunmaktadır.

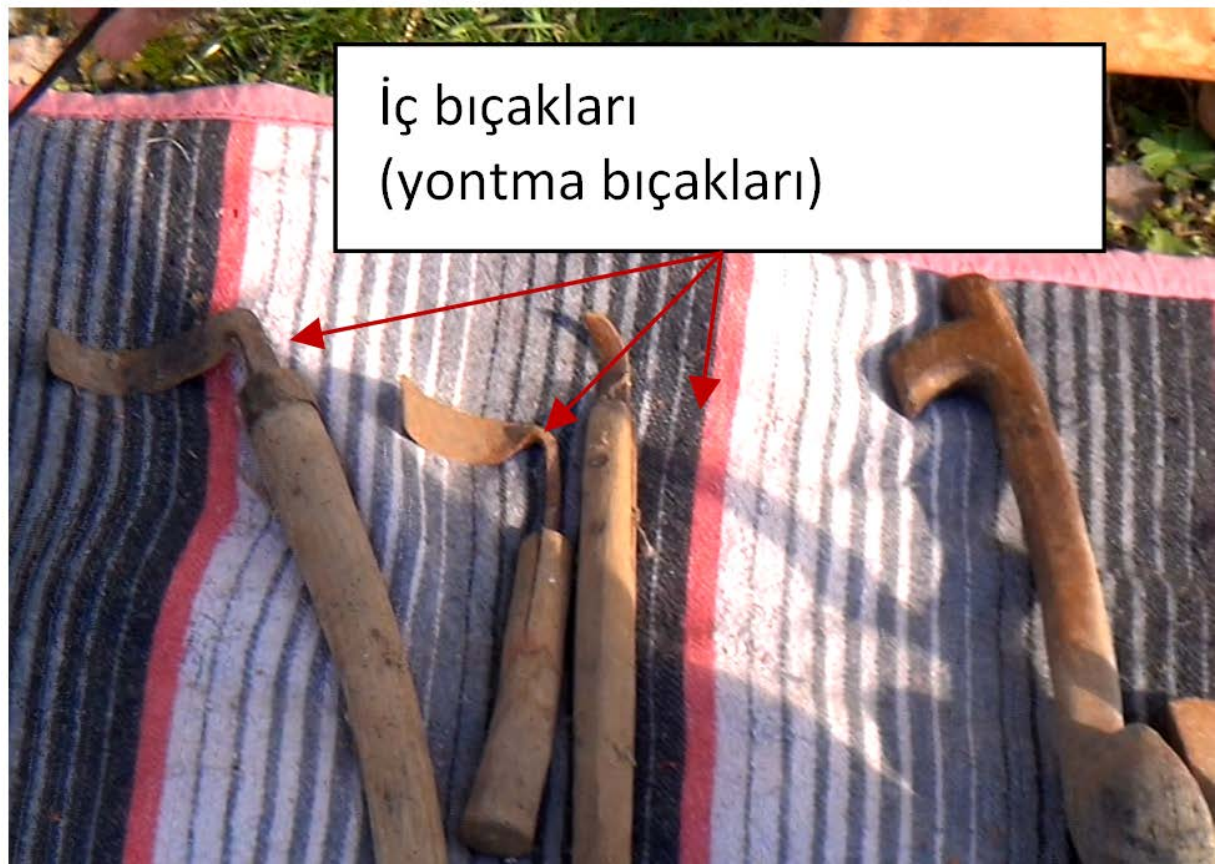

Şekil 38. Ahşap malzemelerin oval şekiller almasını sağlayan iç bıçakları (Fot::Hüseyin Bayraktar) 


\section{SONUÇ VE ÖNERILER}

Geleneksel köy evleri geçmişten edinilen tecrübeler ve coğrafi ortamın gerektirdiği doğal malzemeler ile donatılmış, kırsal yerleşmelerin doğal yapı taşlarını oluşturmuşlardır. Evlerin hem planlama süreçleri hem de yapım süreçleri yöre halkının yaşam gereksinimlerinin merkezinde çevrelenmiştir. Doğal malzemelerden evin yapısal sistemine en uygun malzemelerin seçilmesi, neredeyse her bir parçada el emeğinin bulunması, evin iç mekanının ve dış mekanının geleneksel yaşam tarzının sürdürülmesine uygun yapılması evlerin kültürel bir imge olmasını sağlamıştır.

Araştırma kapsamında incelenen evlerin yapım malzemeleri ve teknikleri, plan tipleri, bahçe/sokak ile ilişkileri gibi özellikler Düzce ili yakın çevresinde Bolu (Seben, Göynük, Mudurnu), Karabük (Safranbolu), Sakarya (Taraklı) gibi yerlerde de benzerlik gösterdiği görülmüştür. Temelde taş kullanılması ve tekil taş temeller üzerine ahşap dikme ve çaprazların yükseltilerek katların oluşturulması, ahşap ağırıklı malzemenin evlerin hem taşıyıcı sisteminde hem de tamamlayıcı elemanlarında kullanılması ile hımış yapının elde edilmesi, plan tipinde sofa merkezli kurgular ve ocaklı odalar, mahremiyetin evin planında sağlandığı gibi bahçe ve sokak ilişkisinin de yine aile mahremiyetine göre düşünülmesi, evlerde işlevselliğin ön planda tutulmasının yanında estetik görselliğin de sağlandığı evler Düzce ve yakın çevresinde bulunan evlerde benzerlikler göstermektedir. Batı Karadeniz Bölgesinin coğrafi ve iklim özellikleri de evlerin oluşum ve benzerliklerinde önemli ilk kriterlerden biridir.

Özellikle kırsal bölgelerde bulunan geleneksel köy evleri kent merkezlerinden uzak oldukları için çok fark edilmemektedir. Bununla birlikte nüfusun köylerden kente gitmesi az sayıdaki bu evlerin geleceklerini tehlikeye atmaktadır. Çalışmada incelenen köylerde en eski ve geleneksel mimariyi en iyi yansıtan örnek evler seçilmeye çalışılmıştır. Bu evlerin yarısı kullanılıyor iken yarısı ise kullanılmamaktadır. Kullanılmayan evler kaderine terk edilmiş neredeyse 80-90 yıllık ömürleri ile yine de dimdik ayakta durmaktadırlar. Geleneksel köy evleri yapısal oluşumlarıyla ve içerisinde geçen yaşam biçimleri ile her biri birer tarih belgesi niteliği taşımaktadır. Çalışmada geleneksel köy evlerinin artık yok olmaya başladığı, tüm köy evleri içerisinde neredeyse \%10 civarlarında bir orana denk gelmesi evlerin oluşumunda yapılan tüm emeklerin, anıların evler ile birlikte yok olacağını göstermektedir.

İncelenen köylerde evlerin tanıtımasına örnek olarak bir köyde ev sahibinin kendi gayretleri ile tanıtımı yapılan geleneksel köy evine rastlanılmıştır. Adı geçen köy Kaledibi köyüdür. Kaledibi köyünde 1888 yılında geleneksel mimari tarzında tek katılı yapılan 130 senelik "Tarihi Ekrem Bey Konağı" adındaki ev köye gelenlere ücretsiz olarak tanıtılmaktadır. Bu tanıtımı ev sahibi tamamen kendi düşüncesiyle ve gayretiyle ev hakkında bilgilerin gelecek kuşaklara aktarılmasını sağlamak amacıyla yapmaktadır. Tanıtılan evin yapısal ve mimari özelliklerinin yanında evin içerisinde daha önce kullanılmış eşyalar hakkında bilgiler alınabilmektedir. Bu tip örneklerin çoğaltılması zaten değerli olan bu evlere artı bir değer katacaktır.

Belirlenen evlerin bir bütün olarak kullanılan eşyalar ile birlikte korunması, "Örnek Geleneksel Köy Evi" ya da "Geleneksel Köy Evi Müzesi" gibi isimler altında her yerleşimin en az bir müzesi olması evlerin belirginliğini ve anlaşılırlığını daha da artırabilecektir. Bölgeye gelen yerli ya da yabancı turistlere köylerde örnek geleneksel köy evlerinin tanıtılması, yine Milli Eğitimde ve Üniversitelerin ilgili bölümlerinde okuyan öğrencilerin örnek geleneksel köy evlerini tanımaları için köylere götürülerek gezdirilmesi hem evlerin korunarak sürdürülebilirliğini hem de geçmişten geleceğe bilgilerin aktarılarak anlamlı ilişkinin kurulması sağlanabilecektir. 


\section{Teşekkür}

Çalışmamızı destekleyen Düzce Üniversitesi Bilimsel Araştırma Projeleri (DÜBAP)'ne, Düzce Valiliği İl Kültür ve Turizm Müdürlüğüne, araştırma yapılan köylerin muhtarlarına, geleneksel köy evleri hakkında bilgi veren yöre halkına, saha çalışmalarında bana yardımcı olan öğrencilerime ve proje arkadaşlarıma çok teşekkür ederim.

Bu çalışmada bilgiler Düzce Üniversitesi 2011.03.06.067 nolu BAP projesi "Düzce Halk Edebiyatı, İnanışlar, Geleneksel Giyim ve Mimari” adlı çalışmadan alınmıştır. Görseller yazar tarafından elde edilmiştir.

\section{KAYNAKLAR}

Alkan, A. (2018) "Orta ve Aşağı Botan Vadisi'ndeki Geleneksel Kır Konutları ve Sürdürülebilirliği Üzerine Bir İnceleme", Turkish Studies Akademic Journal, Volume 13/18, p. 117-142.

Apay, C. A. Önür, Ö. Ö. ve Bideci, A. (2019) “Taraklı'da Sivil Mimarlık Örnekleri ile Ali Pektaş Evi'nin Restorasyonu”, Düzce Üniversitesi Bilim ve Teknoloji Dergisi, 7, 160179.

ARSLANTAŞ, Y. (2014) "Paleolitik Ve Mezolitik (Epi-Paleolitik) Çağ'da Barınma”, Fırat Üniversitesi Sosyal Bilimler Dergisi, Cilt 24, S.2 P.319-343.

Bayraktar, N. T. ve Kishalı, E. (2013). Evaluation of Thermal Behaviour of Traditional Hımış Type Buildings in Kocaeli, Kerpic'13 - New Generation Earthern Architecture: Learning from Heritage International Conference Istanbul Aydin University, Turkey, 1114 September 2013.

Bozkurt, Ö. (2011) "Geleneksel Tekirdağ Evlerinde Kullanılmış Meşe Ahşabının Mekanik Özellikleri ve Kimyasalla Koruma Uygulamalarının Mekanik Özellikler Üzerine Etkisi" Gazi Üniversitesi Politeknik Dergisi, Cilt:14 Sayı: 2 s. 115-119.

Bozkurt, G.S. ve Altınçekiç, H. (2013). "Anadolu'da Geleneksel Konut ve Avluların Özellikleri ile Tarihsel Gelişiminin Safranbolu Evleri Örneğinde İrdelenmesi” Journal of the Faculty of Forestry, Istanbul University 2013, 63(1):69-91.

Burkut, B. E. (2014) "Osmanlı/Türk Evi Mekân Kurgusunu Modern Konut Mimarisinde Okumak (Wright, Corbusier, Eldem ve Cansever'in Konutları)" Basılmış Yüksek Lisans Tezi, Fatih Sultan Mehmet Vakıf Üniversitesi, Mühendislik ve Fen Bilimleri Enstitüsü.

Davulcu, M. (2009) "Sakarya Yöresi Kırsal Yerleşimlerinde Konut Mimarisi ve Ustalık Geleneği Üzerine Bir İnceleme", Kastamonu Üniversitesi Kastamonu Eğitim Dergisi, 687-706, Cilt:17, No:2.

Dikmen, Ç.B. ve Toruk, F. (2015). "Geleneksel Göynük Evlerinin Mekânsal Yapısı ve Koruma Önerileri", Afyon Kocatepe Üniversitesi Sosyal Bilimler Dergisi, Cilt 17, Sayı 1, 99-128.

Doğan, M. (2013) "Türkiye Sanayileşme Sürecine Genel Bir Bakış (A General Outlook on the Industrialization Process of Turkey)", Marmara Coğrafya Dergisi, Sayı: 28, S. 211-231. 
Düzce Taşınmaz Kültür Varlıkları Envanteri, (2014) T.C. Düzce Valiliği, İı Kültür ve Turizm Müdürlüğü, Düzce Valiliği Kültür Yayınları Serisi, No:1, s.10-12.

Eldem, H. S. (1954) "Türk Evi Plan Tipleri”, Plan Eleman ve Tipleri, İstanbul, İstanbul Teknik Üniversitesi, Mimarlık Fakültesi Yayınları, s.11-12.

Ersoy, A. Z. (2003) "Barınma Arketipleri ve Bir Simge Olarak "Ev", Tasarım Kültürü Dergisi, Sayı 1, Sayfa 124.

Kocabıçak, E. ve Pilehvarian, K. N. (2017) "Örneklem Aracılığıyla Ayvacık Kıran Kolu Köyleri Geleneksel Konut Mimarisine bakış. Vernacular Domestic Architecture Through Samples at Ayvacık Kıran Section", YTÜ Mimarlık Fakültesi Megaron Dergisi, 12(3):395-408.

Koçan, N. (2012) "Tarihi Kent Koruma ve Mudurnu (Bolu) Örneği" Ordu Üniversitesi Bilim ve Teknoloji Dergisi, Cilt:2, Sayı:2, 93-102.

Kuban, D. (2007) Osmanlı Mimarisi, İstanbul, Yem Yayınevi, Birinci baskı, sayfa: 470472.

Ovalı, K. P. ve Delibaş, N. (2016) "Yerel Mimarinin Sürdürülebilirliği Kapsamında Kayaköy'ün Çözümlemesi. Analysis of Kayaköy Within the Scope of the Sustainability of the Vernacular Architecture", YTÜ, Mimarlık Fakültesi, Megaron Dergisi, 11(4):515529.

Özgünler, M. (2017) "Kırsal Sürdürülebilirlik Bağlamında Geleneksel Köy Evlerinde Kullanılan Toprak Esası ıapı Malzemelerinin İncelenmesi”, SDÜ Mimarlık Bilimleri ve Uygulamaları Dergisi, 2(2): 33-41.

Şenoğlu, N. (2003/4) “Geleneksel Mimarlık”, TMMOB Mimarlar Odası İzmir Şubesi, Ege Mimarlık Dergisi, sayı 48, s.45-47.

Yaldız, E. ve Asatekin, G. E. (2016) "Anıtsal Yapıların Kullanım Sürecinde Değerlendirilmesine Yönelik Bir Model Önerisi” METUJFA (Cilt 33, S:2) p.161-182.

Yasa, A. A. (2016). "Seben Geleneksel Konut Mimarisi Üzerine Bazı Gözlemler" Hacettepe Üniversitesi Türkiyat Araştırmaları Dergisi, (24), 45-70.

İnternet Kaynakları

URL 1, http://www.duzce.bel.tr/detay.asp?id=2151 [Erişim tarihi: 22.10.2018]

URL 2, http://www.duzce.gov.tr/duzce-sehir-merkezi-kis-gece [Erişim tarihi: 22.10.2018] 